DIW BERLIN

Discussion

Papers

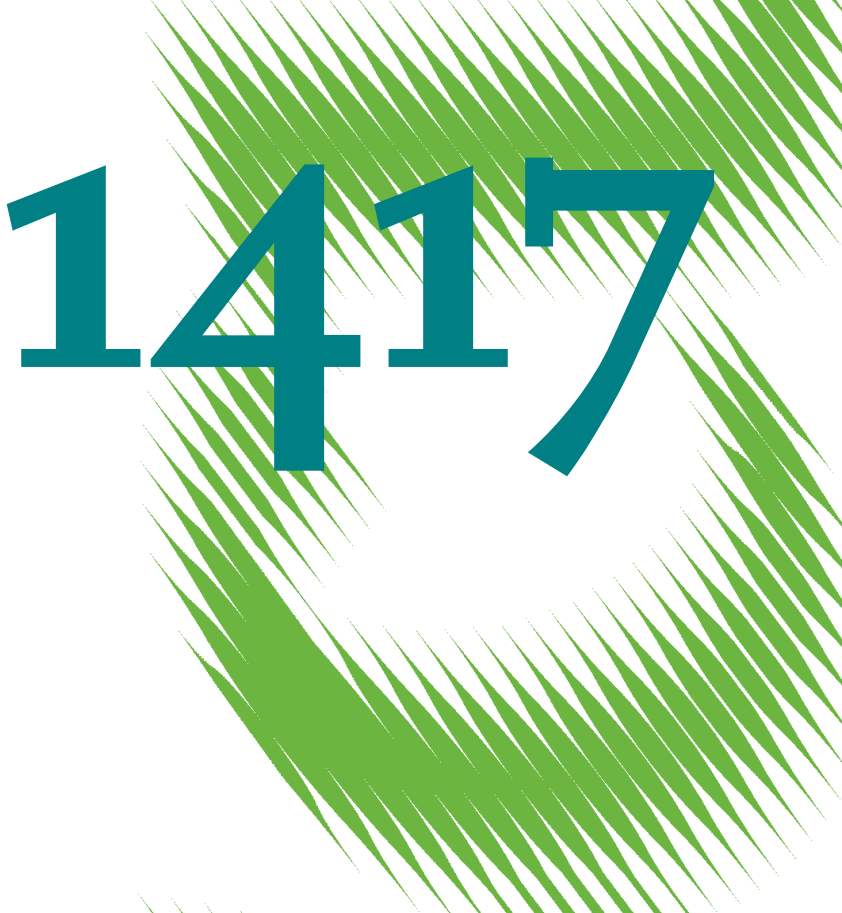

Speculative Price Bubbles in Urban Housing Markets in Germany 
Opinions expressed in this paper are those of the author(s) and do not necessarily reflect views of the institute.

IMPRESSUM

(C) DIW Berlin, 2014

DIW Berlin

German Institute for Economic Research

Mohrenstr. 58

10117 Berlin

Tel. +49 (30) $89789-0$

Fax +49 (30) $89789-200$

http://www.diw.de

ISSN electronic edition 1619-4535

Papers can be downloaded free of charge from the DIW Berlin website:

http://www.diw.de/discussionpapers

Discussion Papers of DIW Berlin are indexed in RePEc and SSRN:

http://ideas.repec.org/s/diw/diwwpp.html

http://www.ssrn.com/link/DIW-Berlin-German-Inst-Econ-Res.html 


\title{
Speculative price bubbles in urban housing markets in Germany
}

\author{
Konstantin A. Kholodilin* Claus Michelsen** Dirk Ulbricht ${ }^{\S}$
}

October 28, 2014

\begin{abstract}
The surge in the German house prices starting in 2010 raised fears about the emergence of a speculative bubble. Given a local nature of housing markets, it is not clear to what extent the bubble, if any, is spread across different cities. In this paper, we test for speculative house price bubbles in 127 large German cities over the last 20 years. Along with testing bubbles for each city separately, we apply two new testing approaches: a panel data and principal components version of explosive root tests. We define bubble as an explosive growth of prices that is not supported by the rent increase. Therefore, to check for the existence of bubbles, we examine prices, rents, and price-to-rent ratios. We find evidence for explosive price increases in many cities, especially for the case of newly built housing. However, only in few urban housing markets prices decouple from their fundamental values. On the national level, we do not see evidence for speculative price movements. Overall, we find that the danger of a build-up of a speculative price bubble in the German housing market is rather moderate.
\end{abstract}

Keywords: speculative bubble, explosive root, German cities.

JEL classification: C21; C23; C53.

\footnotetext{
I The authors would like to thank Jörg Breitung for his valuable comments as well as Dmitry Chervyakov and Georg Wagner for their helpful research assistance.

*Research associate, DIW Berlin, Mohrenstraße 58, 10117 Berlin, Germany, e-mail: kkholodilin@diw.de

**Research associate, DIW Berlin, Mohrenstraße 58, 10117 Berlin, Germany, e-mail: cmichelsen@diw.de.

$\S$ Research associate, DIW Berlin, Mohrenstraße 58, 10117 Berlin, Germany, e-mail: dulbricht@diw.de.
} 


\section{Contents}

1 Introduction $\quad 1$

2 The German housing market: Five stylized facts 4

3 Bubbles in house prices: an econometric approach $\quad 5$

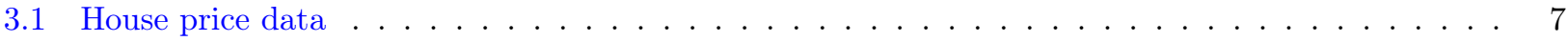

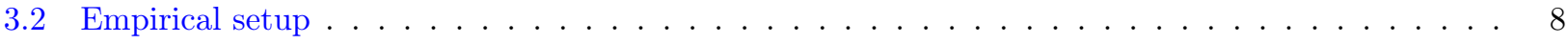

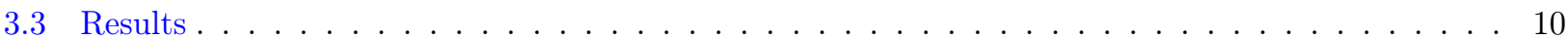

4 Conclusions and policy implications $r$

$\begin{array}{ll}\text { References } & 17\end{array}$

$\begin{array}{lr}\text { Appendix } & 20\end{array}$ 


\section{List of Tables}

1 Chow test: empirical size, power, and estimated break dates for $T=20 \ldots \ldots$. . . . . 20

2 Prices of building plots: importance of first principal component for each city and of each city

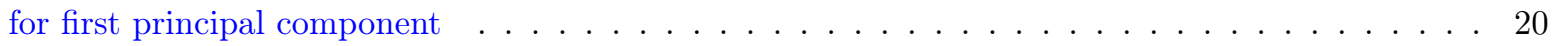

3 Prices of newly built apartments: importance of first principal component for each city and of

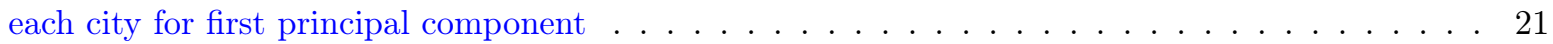

4 Prices of second-hand apartments: importance of first principal component for each city and of

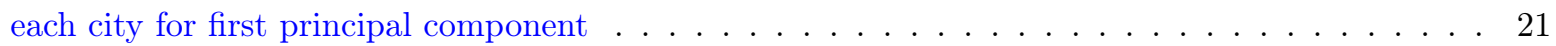

5 Rents of newly built apartments: importance of first principal component for each city and of

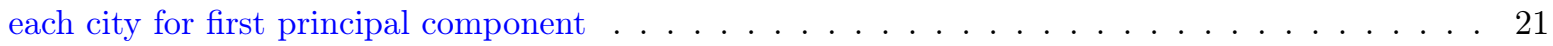

6 Rents of second-hand apartments: importance of first principal component for each city and of

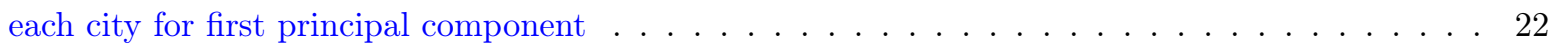

$7 \quad$ Price-to-rent ratios of newly built appartments: importance of first principle component for each

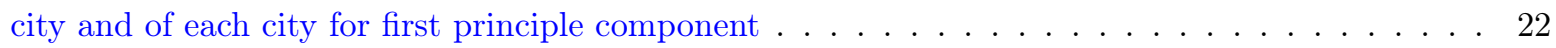

8 Price-to-rent ratios of second-hand appartments: importance of first principle component for each city and of each city for first principle component $\ldots \ldots \ldots \ldots \ldots \ldots \ldots \ldots$

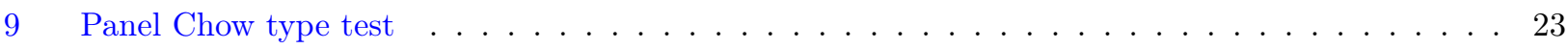

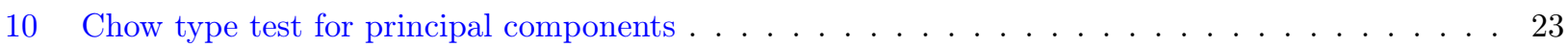

\section{List of Figures}

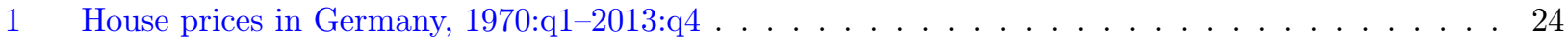

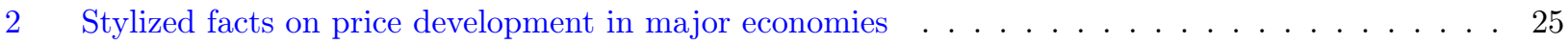

3 Stylized facts on housing investment in major economies . . . . . . . . . . . . . . 25

4 Homeownership rates in major economies $(2012 / 2013) \ldots \ldots \ldots \ldots \ldots$

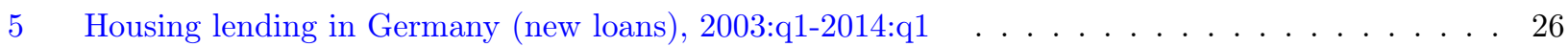

6 House prices in German cities, $1990-2013 \ldots \ldots \ldots \ldots \ldots \ldots \ldots$ 
7 House prices in German cities, 1990-2013 . . . . . . . . . . . . . . . . . . . 28

8 Principal components by share of variance . . . . . . . . . . . . . . . . . . . . 29

$9 \quad$ First principal components of housing variables . . . . . . . . . . . . . . . . . . . 30

10 Chow test statistic of principal components of prices . . . . . . . . . . . . . . . . . 31

11 Chow test statistic of principal components of rents, and price-to-rent ratio . . . . . . . . . . 32

12 Geographical distribution of explosive roots, prices . . . . . . . . . . . . . . . . 33

13 Geographical distribution of explosive roots, rents . . . . . . . . . . . . . . . . . . . 34

14 Chow test by city for prices, rents, and price-to-rent ratios . . . . . . . . . . . . . . . 35 


\section{Introduction}

After a protracted stagnation of housing prices, which lasted for almost two decades, German house prices began to grow at an accelerated pace since late 2010 (see Figure 1). Real house prices, which even had been declining in 2000-2008, started to climb up steeply from the second half of 2010, followed by a flurry of construction activities. Having the lessons from the Great Recession in mind (Duca et al., 2010), current housing market dynamics raised concerns about the formation of a speculative house price bubble among policy makers and central bank staff in Germany. In 2013, the Deutsche Bundesbank reported an overvaluation of German metropolitan residential real estate of up to 25\% (see, Deutsche Bundesbank, 2013; Kajuth et al., 2013). In response, the International Monetary Fund (IMF) calls on the German government for an enhancement of its macro-prudential toolkit, to be prepared for the case of an overheating housing market, which is identified as a potential threat to financial market stability (IMF, 2014). In the light of the extremely expansionary monetary policy by the European Central Bank (ECB), the German minister of finance, Wolfgang Schäuble, said in July 2014 that he would take the warnings by IMF and central bank stuff seriously and keep a close eye on future housing market developments.

In contrast, other discussants do not see the need for immediate political action. They argue that, in international comparison, German house prices are relatively low and house price movements are modest in the light of Germany's sound macro-economic fundamentals, a growing number of immigrants, and increasing rents (Haas et al., 2013; Henger et al., 2012). Moreover, it is argued that house price inflation is concentrated in selected urban markets - particularly in the prosperous metropolitan areas like Berlin, Hamburg, and Munichcities experiencing substantial economic and population growth (Dombret et al., 2013), while in more rural areas house prices remain unchanged at low levels. Finally, it is argued that a speculative house price bubble is always associated with a substantial increase of outstanding mortgage loans and excessive construction activity—both do not apply for the case of real estate investment in Germany. Consequently, descriptive assessments of the housing market conclude that there are no indications of bubbles in German housing markets (Empirica AG, 2014; IMF, 2014).

However, there are good reasons to believe in both stories behind the numbers. Taking a historical perspective over the past 140 years, Jordà et al. (2013) point out that the ingredients for a substantial misalignment of house 
prices and economic fundamentals are present, which make the arguments by the Deutsche Bundesbank and the fears of the IMF appear valid. On the other hand, authors like Kofner (2014) emphasize the stability and the resilience of the German housing market to external shocks. In this light, the conclusion of the non-existence of a bubble in the German housing market seems to be a reasonable result.

A key problem for researchers in this context is that the real-time identification of a bubble is relatively complicated and simply relying on a descriptive analysis of isolated indicators can be misleading. For the German case, poor data availability is an additional obstacle. Indeed, there are only three serious studies addressing the question of whether house prices in Germany are currently disconnected from their fundamental values or not. The first study, by Chen and Funke (2013), analyzes aggregate house price data from 1987 through 2012. The authors apply a relatively new approach proposed by Phillips et al. (2011) and Phillips et al. (2011), which is essentially a unit-root test for explosive behavior in time series data. The authors conclude that, on the aggregate level, no signs for the emergence of a speculative house price bubble can be detected. However, the major shortcoming of this study is the use of aggregate house price information. As it is pointed out by several authors, house price dynamics vary significantly across regions (Goodman and Thibodeau, 2008; Hwang and Quigley, 2006; Abranham and Hendershott, 1996)—thus, signs of bubbles should be barely detectable in national time series data. For an early warning of misalignment, the use of regionally disaggregated data seems to be more appropriate.

The second study, by an de Meulen and Micheli (2013), picks up the spatial dimension of Germany's housing market. The authors analyze monthly data of metropolitan house prices from 2008m1 through 2013m1. Based on more powerful tests, as proposed by Homm and Breitung (2012), they conclude that explosive price movements can only be detected in selected regions and only for the distinct market segment of flats in apartment buildings. In summary, the authors conclude that the signs for a speculative house price bubble are weak. Unfortunately, this study focuses on a very short period of time and some a selected markets, which raises doubts on the generalizability of their findings.

The most prominently cited work is that of Kajuth et al. (2013), who follow a "classical" approach by regressing house prices on market fundamentals. Using data for more than 400 regions in the period from 2004 through 2012, they capture the entire spatial variation of the German housing market. Kajuth et al. (2013) find 
that for most analyzed regions, house prices reflect quite well the economic conditions. However, in metropolitan areas, a substantial overvaluation by up to $25 \%$ is detected, which stands in some contrast to the findings of an de Meulen and Micheli (2013). One explanation might be the quite short period of observation. The authors estimate an "equilibrium" price in the period from 2004 through 2010 and compute the fundamental price for the period from 2010 onwards using the estimated coefficients. However, assuming that housing markets were in equilibrium in the period until 2010 is somehow counter-intuitive. At least in the great recession (2007-2009) the pricing mechanism should have been disturbed substantially, which directly leads to biased estimates of the fundamental prices in the post-crisis period. For this reason, the conclusions of Kajuth et al. (2013) should be treated cautiously.

In absence of clear-cut evidence in favor or against the existence of a housing market bubble, a well-grounded judgment by policy makers and central bank staff on this issue is hardly possible. In this respect, the present study provides additional empirical evidence, based on a much more extensive data set and more elaborate methods compared to previous research. First, this study is based on a very large panel comprising 127 German cities and covering the period from 1996 through 2013. Using these data allows us to observe an entire housing market cycle and, moreover, to account for heterogeneity across urban housing markets. Second, we distinguish between different housing market segments - existing dwellings, newly built dwellings, building plots - and we consider the increase of rents in our identification strategy of house price bubbles. Compared to previous studies, this clearly increases accuracy of the analysis. Third, we further develop existing tests for price bubbles: We conduct a panel-data version of the Chow-type test for explosive roots. Moreover, we apply this test to the first principal components of the individual city-specific price indices, which reflects a common trend in the house prices/rents across various cities. Fourth, we use a more precise definition of a bubble: We consider price movements as bubbles when the explosive growth of prices is not supported by the rent increase. Therefore, to check for the existence of bubbles, we examine not only prices but also rents and price-to-rent ratios.

We find explosive price increases in many cities, in particular in the market for newly built housing. However, only in few of them, the prices appear to be disconnected from their fundamental values. On a national level, we fail to detect a speculative bubble in the apartment prices.

The paper is organized as follows. In section 2, we present stylized facts of the contemporary German housing 
market. Section 3 provides a definition of a price bubble and delineates our empirical approach. Subsection 3.1 describes the data on house prices in German cities that are used in the study. Subsection 3.2 discusses the empirical setup of the study, while in subsection 3.3 the tests for speculative bubbles are carried out and their results are discussed. Finally, section 4 draws conclusions.

\section{The German housing market: Five stylized facts}

Before starting the statistical analysis of house price dynamics, it is worthwhile to take a closer look at the housing market developments in Germany over a longer period of time and in a cross-country comparison.

Stylized fact 1: Long period of declining real house prices. Unlike the markets in many other major economies, the German housing market did not experience a boom at the start of the 2000s. Real house prices even declined between 1996 and 2008. This, however, can be interpreted as a response to the reunification boom in the early 1990s, when, especially in East Germany, price movements were not supported by economic fundamentals (Michelsen and Weiß, 2010).

Stylized fact 2: Increased affordability of housing - but also risk taking behavior. The moderate price development is also reflected in other indicates like the price-to-rent and the price-to-income ratio, both of which were declining since the 1980s in Germany; only starting to increase around 2010 (see Figure 2). In most other countries, price-to-rent and price-to-income ratios were much more volatile. In historical comparison, the current level of these measures can still be rated as moderate in Germany. However, the recent increase of these ratios is quite strong, particularly that of the price-to-rent ratio, which indicates that investors are willing to take greater risks with real estate investment.

Stylized fact 3: Weak construction activity in a less volatile market. Construction activities have been weak in Germany since late 1990s (see Figure 3). In comparison to the early 1990s - the period of reunification - housing permits dropped substantially. This pattern is also reflected in data on investment in new real estate and the ratio of residential real estate investment to GDP, which both have been decreasing continuously from the mid-1990s. All three indicators began to rise in 2010, following the trend of real house 
prices. However, the recovery is, in comparison to earlier years and to other economies, relatively moderate. Housing investments in other countries tend to react more quickly to price movements and show a much more volatile pattern.

Stylized fact 4: Low homeownership rate. The stability of the German housing market is often explained by a relatively low homeownership rate. Indeed, German homeownership rate is substantially below those of other major economies (see Figure 4). In situations when house prices swing up, households have an incentive to sell their property and to reinvest in other real estate, particularly when interest rates are only fixed in the short run, e.g., up to five years. Investors might speculate that they can refinance their loans with better conditions if the value of their collateral increases. The low ownership rate indicates a higher resilience of the German housing market against speculative investment behaviour.

Stylized fact 5: Stable volume of new mortgage loans and high share of long-term fixed interest rates. The fifth stylized fact shows that, in contrast to typical Anglo-Saxon housing market developments, the current upswing of the German market is not associated with an increase of the volume of new credit to private households. Since 2011, new housing lending remained relatively stable around 16 billion euros per month. Moreover, the share of new contracts with long- and medium-term fixed interest rates is also stable.

The stylized facts indicate that the German housing market is in good condition. In the light of the protracted stagnation of house prices and rents between 2000 and 2010, sound economic fundamentals seem to cover recent price increases. Moreover, the data on housing lending indicate that this upswing is not credit driven. Nevertheless, these findings do not imply that recent house price movements are sustainable - but it allows concluding that the threat of price misalignment to the economy is far lower compared to other markets, where the indicators, in particular, the share of short-term mortgage loans, are much more volatile.

\section{Bubbles in house prices: an econometric approach}

Economists are often blamed for having not foreseen the developing house price bubble and its harmful consequences for the world economy prior the Great Recession. There have been plenty of signs for a misalignment of house prices to their fundamentals, like excessive lending to private household, explosive price movements, and 
sharply increasing construction activities. Indeed, many studies conducted before 2007 found that house prices were not disconnected from their fundamentals (see, e.g., Himmelberg et al., 2005; Smith and Smith, 2006; McCarthy and Peach, 2004). In fairness, one must note that there were a couple of studies that indeed warned about a potential house price bubble in major economies like the United States (see, e.g., Case and Shiller, 2003; Belke and Wiedmann, 2005; Fernández-Kranz and Hon, 2006). Detecting a bubble ex ante, however, is not as straightforward as declaring past price movements to be unsustainable. There exist many theories that may explain seemingly unsustainable developments by rational behavior of agents (for a comprehensive overview of the existing models, see, Brunnermeier, 2008).

Our analysis and empirical identification strategy of housing market bubbles follows the well-established ideas of the Gordon growth model (Gordon, 1959). The underlying intuition is that asset prices are fundamentally determined by future dividends in the period of ownership and moreover by future asset price increases. Under the assumption of perfectly informed and rational agents, price increases are again solely determined by dividends earned in the period after the next sale.

In the real estate context, this implies that house prices are - in the long run - tied to the development of rents. Under the standard no arbitrage condition, the house price can thus be expressed as

$$
P_{t}=\frac{E_{t}\left[P_{t+1}+R_{t+1}\right]}{1+i},
$$

where $P$ is the real estate price in period $t, R_{t+1}$ denotes the rental income in period $t, i$ the risk-free interest rate and $E[\cdot]$ rational expectation, conditional on the information available (see Homm and Breitung 2012; an de Meulen and Micheli 2013). The fundamental price $P^{F}$ can be determined by forward iteration of equation (1).

$$
P_{t}^{F}=\sum_{n=1}^{\infty} \frac{1}{(1+i)^{n}} E_{t}\left[R_{t+n}\right]
$$

However, there is a unique solution for equation (2) under the transversality condition

$$
\lim _{k \rightarrow \infty} E_{t}\left[\frac{1}{(1+i)^{k}} P_{t+k}\right]=0 .
$$


If the actual price process contains additional elements, like a bubble component $B$, the pricing equation becomes

$$
P_{t}=\lim _{k \rightarrow \infty} E_{t}\left[\frac{1}{(1+i)^{k}} \cdot\left(\hat{P}_{t+k}+(1+i)^{k} B_{t}\right)\right]+P_{t}^{F}
$$

In this case, there exist infinitely many solutions. Today's house price can be decomposed in two elementsone covering the fundamental value, determined by future rental income and another that is related to potentially speculative motivations. In case of a bubble, any rational investors should expect the house price to increase at rate $i$. Price increases then become self-fulfilling processes. Because all rational investors expect other investors to pay a price $P_{t+1}^{F}+B_{t+1}$, they are willing to pay $P_{t}^{F}+B_{t}$ in period $t$.

There are various approaches to empirically identify the existence of a speculative bubble in housing markets (for a first overview, see, Cho, 1996). One strand of the literature explicitly builds on the theoretical considerations above. Recently, Homm and Breitung (2012) developed an empirical test to identify unusually strong increases in asset prices. The basic idea is to analyze the roots of an autoregressive process. If asset prices represent discounted expected incomes - in the housing context rental income - it is unlikely that prices grow at an exponential rate in the long run. The approach to detect a bubble is to test for an explosive root against the alternative of a unit root, the latter reflecting the rational expectations hypothesis. We follow this approach and develop a test for speculative price movements in panel data, to account for sub-national variation of housing market development.

\subsection{House price data}

The German data on house prices and rents, especially in individual cities, are quite poor. See Hoffmann and Kurz (2002); Hoffmann and Lorenz (2006), and Georgi and Barkow (2010) for an overview of the house price data. Typically, the data are either too short, cover too few locations, or reflect only advertised prices.

In the present analysis, we take advantage of a data set on prices and rents that is provided by real estate analysts of bulwiengesa $A G$. The company has been collecting real-estate data and constructing corresponding price indices for over 30 years $^{1}$. These data are used, among others, by the Deutsche Bundesbank to examine the

\footnotetext{
${ }^{1}$ For more details see Hampe and Wenzel (2011).
} 
developments in German real-estate market. Furthermore, OECD utilizes the data to construct German-wide house price index for its international database.

The data set covers average transaction prices and rents for 127 large German cities from 1990 through 2013. This makes it is unique in terms of its geographical and temporal coverage. More importantly, the use of these data allows us to tackle main weaknesses of previous studies on the German housing market (see section 1).

In our analysis, we concentrate upon the following five variables:

- average purchase price of plots of land for multi-family houses;

- average purchase price of newly built apartments;

- average purchase price of second-hand apartments;

- average rent of newly built apartments; and

- average rent of second-hand apartments.

In addition, using the variables listed above we computed price-to-rent ratios for newly built and second-hand apartments.

The dynamics of the purchase prices, rents, and price-to-rent ratios in all cities are depicted in Figures 6 and 7, respectively, in form of boxplots to characterize their distribution. It is clear that in both market segments (primary and secondary markets) prices went up strongly starting in 2010. This is especially true for the cities where house prices were already high before 2010 .

\section{$3.2 \quad$ Empirical setup}

In this section, we will apply the Chow-type unit root statistic to test for explosive roots in the German house price and rent data. We define a speculative bubble using two criteria: first, prices must grow explosively. Second, the actual housing prices need to deviate from the fundamental values, which are determined by the rents. The application of the Chow type test to house prices allows testing the first criterion. The second criterion can be checked by applying the test to rents or price-to-rent ratios. A bubble is detected if explosive 
roots are found in both house prices and price-to-rent ratios. ${ }^{2}$ When the explosive roots are found in both prices and rents but not in their ratios, we do not detect a speculative house price bubble, since the strong price increases are to a large extent driven by the high rent dynamics.

Here, we use two different test strategies. The first testing strategy consists in applying a panel-data version of the Chow-type test for explosive roots. The panel data allow exploiting the cross-section dimension, given a very short time dimension of our data. Under this approach, we examine a null hypothesis of no explosive roots in any of the city-level housing markets. The rejection of the null is a minimum condition for the existence of a bubble in German housing market.

The second strategy consists in extracting the principal components and testing the first principal component for explosive roots, instead of conducting the tests for each city separately. The reason for this is twofold. Firstly, the individual city-level time series are relatively volatile, whilst the principal component should be smoother due to canceling out of the individual fluctuations. Secondly, the first principal component can be interpreted as a countrywide house price dynamics and, provided that a speculative bubble will be discovered, it can be treated as a house price bubble at the national level. The resulting factor loadings can be interpreted as contributions of each city to the national bubble.

Given a very short sample of house prices in German cities, we need to investigate the size and power of the test for speculative bubbles when applied to very short samples. In order to do this we carry out simulations.

The simulations are conducted using a framework suggested by Homm and Breitung (2012). We generate an $\operatorname{AR}(1)$ process with a time-varying autoregressive parameter:

$$
y_{t}=\rho_{t} y_{t-1}+u_{t}
$$

where $u_{t}$ is a white noise process such that $E\left(u_{t}\right)=0, E\left(u_{t}^{2}\right)=\sigma^{2}$, and $y_{0}=c<\infty$.

$$
\rho_{t}=\left\{\begin{array}{r}
1, \quad \text { for } t=1, \ldots,\left[\tau^{*} T\right] \\
\rho^{*}>1, \text { for } t=\left[\tau^{*} T\right]+1, \ldots, T
\end{array}\right.
$$

\footnotetext{
${ }^{2}$ In case of the price-to-rent ratios, given that the ratios should be stationary in the long run, the Chow-type test having the null hypothesis of a random walk, has low power. Thus, it is rather conservative: if the null hypothesis is rejected, then we can be pretty sure to have exploding prices that have decoupled from their fundamentals.
} 
Thus, this process models a single deterministic bubble that occurs after time $\left[\tau^{*} T\right]$.

Simulations were conducted for various values of $\rho^{*}, \tau^{*}$, and $T$. We considered the following values of the autoregressive parameter $\rho^{*} \in[1.03,1.05]$ and the time fraction $\tau^{*} \in[0.7,0.8,0.9]$ that resemble the German case the most, given that the price increase started in 2010, that is, in 0.875-th fraction of the sample. Only one value of sample length was used, namely $T=20$, which corresponds to a real-life situation where only 20 years of observations are available. The number of replications is 2000. One test statistic was used that turned out to be the best, according to Homm and Breitung (2012): Chow-type unit root statistic for a structural break ${ }^{3}$.

Simulation results for Chow test are reported in Table 1 . The empirical power of the test is very low. The break dates are detected very imprecisely. The good news is a relatively low size of the test. Thus, if the test would reject the null hypothesis of no speculative bubble, its results should be considered as relatively robust.

\subsection{Results}

Despite the fact that the data begin in 1990, we start our analysis in 1996 in order to control for the boom following German re-unification in 1990.

To the best of our knowledge, this paper is the first to apply a panel version of the Chow type explosive root test. Its test statistic is computed as a mean of the city-specific Chow type test statistics. The critical values for this test were obtained using bootstrap as follows:

1. Growth rates, or differences of logarithms of the original price time series were computed: $\Delta y_{i t}=y_{i t}-$ $y_{i, t-1}$.

2. The growth rates were collected in a vector $\Delta y_{t}=\left(\Delta y_{1 t}, \Delta y_{2 t}, \ldots, \Delta y_{N t}\right)$.

3. Out of this vector the values were drawn with replacement: $\Delta y_{i t}^{*}$.

4. Simulated series were generated using the bootstrapped growth rates: $y_{i t}^{*}=y_{i 1}+\Delta y_{i 2}^{*}+\ldots+\Delta y_{i t}^{*}$. The number of simulations was set to 1000 .

5. The Chow type tests for explosive roots were carried out for each city and then the panel test statistic was computed as the mean of the city-specific test statistics: $\bar{\tau}^{D F C}=\frac{1}{N} \sum_{i=1}^{N} \tau_{i}^{D F C}$, where $\tau_{i}^{D F C}$ is the

\footnotetext{
${ }^{3}$ All the computations in this paper are carried out using the codes written by the authors in the statistical programming language $\mathbf{R}$ (see R Core Team, 2013). These codes are available upon request.
} 
Chow type test statistic for city $i$.

6. Based on the distribution of the mean test statistics, critical values were computed as 90th, 95th, and 99th percentiles.

We start from examining the test results obtained for the individual cities. In case of building plots, the null hypothesis of random walk can be rejected at $1 \%$ significance level for 16 cities (standard test, critical value 2.6285, see Table 1 in Homm and Breitung (2012)). In case of newly built and second-hand apartments, it can be rejected for 61 and 19 cities, respectively. However, for rents of newly built and second-hand apartments, it can be rejected for 36 and 33 cities, while for price-to-rent ratios for newly built apartments and second-hand apartments for only 5 and 1 , respectively.

Figure 12 shows the geographical distribution of the test results for housing prices at the local city-level markets. Green dots denote cities for which no explosive roots can be found. Yellow, orange, and red dots indicate cities which have one, two, and three explosive roots in the data, respectively. Most of the cities with explosive roots in all price series are in the West, particularly the South of Germany. Some of the bigger cities, like Hamburg, Cologne, and Munich, have explosive roots in all three segments analyzed. Cities without explosive roots tend to be located in East Germany or the regions of North-Rhine Westphalia that have been most severely affected by deindustrialization.

Figure 13 shows an analogous map for the rents of newly built apartments and second-hand apartments. For most of the city-level markets, explosive roots in the prices are accompanied by explosive roots in the rents. However, some cities like Munich have explosive roots in all price series but not in the rents. This can be explained by the fact that Munich has been experiencing a steady but not extraordinarily high rent increases for many years.

Finally, Figure 14 plots the average annual change in rents against average annual changes in prices of newly built apartments (blue and green colored) and second-hand apartments (gray and black colored) of each city from 2010 to 2013. The dashed black (dotted green) line represents the average of the price changes of newly built (second-hand) apartments of all cities. The empty gray (blue) circles represent cities that have neither an explosive root in the newly built (second-hand) apartment prices nor in the respective price-to-rent ratios. Black (green) circles denote cities that have an explosive root in the prices of newly built (second-hand) apartments. 
Filled black (green) points denote cities that have an explosive root in the prices and in the price-to-rent ratios of newly built (second-hand) apartments. Thus, the latter indicate a bubble.

Accordingly, 4 out of 6 of the green and black points representing bubbles in newly built and second-hand apartments are close to or below the overall average of rent changes, while they are markedly higher than the average of price increases. For instance, Munich has an explosive root in the price-to-rent ratios of second-hand apartments. The average 2010 to 2013 price change is about three times the average price change of all cities over the same period, while the average rent increase is more or less at the overall average. Only Solingen and Mönchengladbach, both having bubbles in newly-built apartments, have averages that are lower than the average of price changes of all cities. However, for Solingen the increases in prices are more than double the average of rent increases. For Mönchengladbach the increase in prices is more than six times the increase in rents. This is related to the stagnating rents in those cities.

All city-level markets with a bubble are West German. None of the cities has a bubble in both the markets for newly built and second-hand apartments.

After the bootstrapped critical values were computed, the panel Chow type tests were conducted for the actual data. The results of testing are reported in Table 9. It can be seen that the mean Chow type test statistic in the case of newly built apartments exceeds even the $1 \%$ critical values. Thus, the null hypothesis of no city having a speculative bubble can be rejected in favor of the alternative that some cities have speculative bubbles in the prices of newly built apartments. For building plots, second-hand apartments, rents of newly built and second-hand apartments, and price-to-rent ratios of newly built and second-hand apartments the null hypothesis can not be rejected.

Now, we turn to the second testing strategy, which amounts to testing explosive roots in the first principal components. The first panel in Figure 8 shows the shares of variance of the price series explained by each principal component. The proportion of variance explained by the first principal component is $49 \%$ for newly built apartments, followed by $36 \%$ for second-hand apartments, and $27 \%$ for building plots. The second panel in Figure 8 shows the shares of variances explained by the principal components for the rents of newly built and second-hand apartments. The first principal component explains $46 \%$ of the former and $31 \%$ of the latter. The last panel presents the corresponding values for the price-to-rent ratios of newly built apartments and 
second-hand apartments. Here, the first principal component explains $17 \%$ of the former and $20 \%$ of the latter.

Figure 9 shows the first principal components of the prices of building plots, newly built, and second-hand apartments (first plot), the first principal components of the rents of newly built and second-hand apartments (second panel), and the first principal components of the price-to-rent ratios of newly built and second-hand apartments (third panel).

All three price series show that the first principal components can be interpreted as reflecting the recent price booms. They follow a downward trend from 1996 to 2005. Since 2008 the principal components grow and have largely overcompensated the preceding downward trend. Starting before 2000, the first principal components of the rents follow an upward trend, which has accelerated since 2010. However, for second-hand apartments, the increase slowed down a little in 2013. In line with the trends the first principal components of prices and rents, the first principal components of the price-to-rent ratios have been falling until 2008 for newly built apartments and 2011 for second-hand apartments. After that, increases have been markedly higher for newly built apartments than for second-hand apartments.

The left side of Tables 2-7, and 8 show the shares of variance of the prices that are explained by the first principal component, respectively for housing plots, newly built apartments, second-hand apartments, rents of newly built apartments, rents of second-hand apartments, price-to-rent ratios of newly built apartments, and price-to-rent ratios of second-hand apartments. They include the 10 cities for which the first principal component explains the highest share of the variance and the 10 cities for which the first principal component explains the lowest share of variance. The right side of the tables presents the weight each individual city has in the respective first principal component. They contain the 10 cities that have the highest and the 10 cities that have the lowest weights in the first principal component.

The variance of prices (Tables 2, 3, and 4) and rents (Tables 5 and 6) can best be explained by the first principal component in booming western and southern German cities like Erlangen, Ingolstadt, and Ulm. However, also some East German metropolises like Leipzig, Dresden, and Berlin make it into the top ten. Many of the cities that are least explained by the first principal component are part of the regions that experienced a protracted deindustrialization over the last decades, particularly in the federal state of North Rhine-Westphalia, like Gelsenkirchen, Oberhausen, and Remscheid, but also Plauen in Saxony. The weights of each city of the 
first principal component largely correspond to the overall picture of the shares of variance.

With respect to the variance of price-to-rent-ratios the results are less clear cut (Tables 7 and 8). Berlin is among the 10 cities whose variance is least explained by the first principal component of the rents of newly built apartments. However, it is among the 10 cities most explained by the first principal component when it comes to second-hand apartments.

Table 10 shows the Chow test statistics and the 1\%,5\%, and 10\% bootstrapped critical values for each of the 7 principal components. The bootstrapped critical values exceed simulated critical value at the $1 \%$ and $5 \%$ level of 2.6285 and 1.9327, respectively presented in Table 1 in Homm and Breitung (2012). Thus, the former are more conservative, than the latter. The null hypothesis can be rejected at the $1 \%$ level for prices of newly built apartments and at the $5 \%$ level for rents of newly built apartments. It is close to the $10 \%$ critical value for prices of building plots.

Figures 10 and 11 show the Chow-type statistic proposed by Homm and Breitung (2012) applied to the principal components and the suprema represented by vertical lines of prices, rents, and price-to-rent ratios, respectively.

\section{Conclusions and policy implications}

There is an intense debate whether there exists the threat of a speculative price bubble in the German housing market. Interest rates fell to historically levels following the 2008 financial crisis and alternative assets lost their attractiveness - the excessive liquidity flooded the housing market. Coupled with an increased migration towards metropolitan regions, this led to strong house price increases, particularly in urban areas. Since the memories of the latest house price busts in several countries, for example, Spain, the UK, and the USA, are still vivid, doubts arose about the sustainability of price surges in the German housing market and their potential risks for the economy, not only in Germany.

The aim of this paper was to identify potentially non-sustainable price movements. Therefore, we further developed existing tests for speculative house price bubbles and applied them to data from 127 large German

cities in the period 1996 through 2013. To test for the existence of bubbles, we performed the Chow type unit root test for each city separately in a panel context and for the national trend represented by the first principal 
component. Based on this analysis, we can draw four main conclusions.

1. We find explosive price movements in about half of the cities analyzed. More precisely, the prices for building plots show an explosive trend in 16 cities; the prices of newly built apartments increase by an accelerated pace in 61 cities while this is the case for second hand apartments in only 19 cities.

2. However, the tests for rents reveal that these increase explosively in 36 cities for newly built and in 31 cities for second hand apartments. In the price-to-rent ratio, explosive movements can be detected for only five cities in newly built apartments and in second hand dwellings solely in Munich.

3. Both findings together indicate the existence of speculative price bubbles in selected urban housing markets, mostly in west Germany and mostly in newly built apartments. The stricter criterion for a speculative bubble - the price-to-rent ratio - indicates non-sustainable developments in only six cities. Thus, prices decouple from their fundamental values only in very few urban areas. Vice versa, our results on second hand apartments also indicate substantial undervaluation in cities where rents increased strongly, while prices did not.

4. At the Germany-wide level, our results do not indicate the existence of a speculative bubble in apartment prices. While we detect explosive behavior in the first principal component of newly built apartment prices, these price movements appear to be covered by the rent development, which is also of an explosive nature. Consequently, no bubble can be detected in the price-to-rent ratio.

To summarize, our results suggest that in Germany house prices overall align quite well with housing market fundamentals. However, we detected indicators for local house price bubbles in specific housing market segments - in roughly one fourth of the cities in our sample, we found that price increases show an explosive behavior, while rents for newly built apartments do not. When applying the more conservative criterion, the price-to-rent ratio, the number of cities where bubbles can be detected is even smaller. These results are largely in line with the assessment of most housing market analysts who find that the German housing market is quite stable. However, while most discussants argue that there is no need to worry at all, we conclude that decision makers are well advised to have a close eye on the housing market and to keep track of regional market developments. While it is true that unlike in Spain or the United States, the boom in the German housing 
market is not credit driven on aggregate - as Figure 5 shows, housing lending in Germany has been stable both in absolute and in relative terms since 2003 - this does not necessarily mean that housing lending on the regional level has not increased substantially. Nevertheless, the potential threat of bursting local house prices bubbles to the entire economy can be judged as modest. Thus, immediate political action on a country-wide level is not required. 


\section{References}

Abranham, J. and P. Hendershott (1996). Bubbles in metropolitan housing market. Journal of Housing Research 7(2), 191-207.

an de Meulen, P. and M. Micheli (2013). Droht eine Immobilienpreisblase in Deutschland? Wirtschaftsdienst 93(8), 539-544.

Belke, A. and M. Wiedmann (2005). Boom or bubble in the us real estate market. Intereconomics 40(5), 273-284.

Brunnermeier, M. K. (2008). Bubbles. The New Palgrave Dictionary of Economics 2.

Case, K. E. and R. J. Shiller (2003). Is there a bubble in the housing market? Brookings Papers on Economic Activity 2003(2), 299-362.

Chen, X. and M. Funke (2013). Renewed Momentum in the German Housing Market: Boom or Bubble? CESifo Working Paper (No. 4287).

Cho, M. (1996). House price dynamics: A survey of theoretical and empirical issues. Journal of Housing Research 7, 145-172.

Deutsche Bundesbank (2013). Monatsbericht Oktober 2013.

Dombret, A., R. Braun, N. B. Rottke, C. Y. Oertel, A. Mense, and J. Schumacher (2013). Miet-und Immobilienpreissteigerungen: Droht eine Immobilienblase? Ifo Schnelldienst 66(02), 03-20.

Duca, J. V., J. Muellbauer, and A. Murphy (2010). Housing markets and the financial crisis of 2007-2009: Lessons for the future. Journal of financial stability 6(4, Sp. Iss. SI), 203-217.

Empirica AG (2014). empirica-blasenindex ii/2014.

Fernández-Kranz, D. and M. T. Hon (2006). A cross-section analysis of the income elasticity of housing demand in spain: Is there a real estate bubble? The Journal of Real Estate Finance and Economics 32(4), 449-470.

Georgi, S. and P. Barkow (2010). Wohnimmobilien-Indizes: Vergleich Deutschland — Großbritannien. Zentraler Immobilien Ausschuss e.V. 
Goodman, A. C. and T. Thibodeau (2008). Where are the speculative bubbles in US housing markets? Journal of Housing Economics 17(2), 117-137.

Gordon, M. J. (1959). Dividends, earnings, and stock prices. Review of Economics and Statistics 41(2), 99-105.

Haas, H., R. Henger, and M. Voigtländer (2013). Reale Nachfrage oder bloße Spekulation: Ist der deutsche Wohnimmobilienmarkt überhitzt? Technical report, IW policy paper.

Hampe, S. and F. Wenzel (2011). BulwienGesa-Immobilienindex 1975 - 2010. Technical report, BulwienGesa AG.

Henger, R., K. Pomogajko, and M. Voigtländer (2012). Gibt es eine spekulative Blase am deutschen Wohnimmobilienmarkt. Hg. v. Institut der deutschen Wirtschaft Köln (IW-Trends-Vierteljahresschrift zur empirischen Wirtschaftsforschung, 3).

Himmelberg, C., C. Mayer, and T. Sinai (2005). Assessing high house prices: Bubbles, fundamentals, and misperceptions. NBER Working Paper Series 11643.

Hoffmann, J. and C. Kurz (2002). Rent indices for housing in West Germany 1985 to 1998. Working Paper Series 116, European Central Bank.

Hoffmann, J. and A. Lorenz (2006). Real estate price indices in Germany: past, present and future. OECD-IMF Workshop "Real Estate Price Indexes", Paris, November 6-7, 2006.

Homm, U. and J. Breitung (2012). Testing for speculative bubbles in stock markets: a comparison of alternative methods. Journal of Financial Econometrics 10(1), 198-231.

Hwang, M. and J. M. Quigley (2006, August). Economic Fundamentals In Local Housing Markets: Evidence From U.S. Metropolitan Regions. Journal of Regional Science 46(3), 425-453.

IMF (2014). Germany - selected issues. IMF Country Report 14/21\%.

Jordà, Ò., M. H. Schularick, and A. M. Taylor (2013). Sovereigns versus banks: credit, crises, and consequences. Technical report, National Bureau of Economic Research. 
Kajuth, F., T. A. Knetsch, and N. Pinkwart (2013). Assessing house prices in Germany: Evidence from an estimated stock-flow model using regional data. Discussion paper Deutsche Bundesbank 46/2013.

Kofner, S. (2014). The German housing system: fundamentally resilient? Journal of Housing and the Built Environment 29(2), 255-275.

McCarthy, J. and R. W. Peach (2004). Are home prices the next bubble? FRBNY Economic Policy Review $10(3), 1-17$.

Michelsen, C. and D. Weiß (2010). What happened to the East German housing market? A historical perspective on the role of public funding. Post-Communist Economies 22(3), 387-409.

Phillips, P. C., S.-P. Shi, and J. Yu (2011). Testing for multiple bubbles. Research Collection School Of Economics.

Phillips, P. C., Y. Wu, and J. Yu (2011). Explosive behavior in the 1990s NASDAQ: When did exuberance escalate asset values? International economic review 52(1), 201-226.

R Core Team (2013). R: A Language and Environment for Statistical Computing. Vienna, Austria: R Foundation for Statistical Computing.

Smith, M. H. and G. Smith (2006). Bubble, bubble, where's the housing bubble? Brookings Papers on Economic Activity 2006(1), 1-67. 


\section{Appendix}

Table 1: Chow test: empirical size, power, and estimated break dates for $T=20$

\begin{tabular}{c|c|c|cc}
\hline $\begin{array}{c}\text { Autoregressive parameter, } \\
\rho^{*}\end{array}$ & $\begin{array}{c}\text { Break point, } \\
\tau^{*}\end{array}$ & Size and power & \multicolumn{2}{|c}{ Break date } \\
\cline { 3 - 5 } & & 0.059 & & \\
\hline size & & 0.088 & 0.649 & 0.261 \\
1.02 & 0.7 & 0.076 & 0.656 & 0.262 \\
& 0.8 & 0.082 & 0.668 & 0.263 \\
\hline \multirow{3}{*}{1.05} & 0.9 & 0.144 & 0.664 & 0.251 \\
& 0.7 & 0.129 & 0.680 & 0.246 \\
& 0.8 & 0.109 & 0.683 & 0.257 \\
\hline
\end{tabular}

Table 2: Prices of building plots: importance of first principal component for each city and of each city for first principal component

\begin{tabular}{|c|c|c|c|c|c|c|c|}
\hline \multicolumn{4}{|c|}{ Share of variance explained by first principal component } & \multicolumn{4}{|c|}{ Weight of each city in first principal component } \\
\hline City & Highest value & City & Lowest value & City & Highest value & City & Lowest value \\
\hline Erlangen & 69.6 & Gelsenkirchen & 0.1 & Bayreuth & 46.4 & Herne & -1.3 \\
\hline Bayreuth & 57.7 & Solingen & 0.1 & Leipzig & 23.9 & Krefeld & -1.5 \\
\hline Passau & 47.4 & Siegen & 0.1 & Berlin & 22.6 & Gießen & -1.5 \\
\hline Darmstadt & 40.3 & Bochum & 0.1 & München & 21.7 & Bielefeld & -2.0 \\
\hline Fulda & 37.0 & Albstadt & 0.0 & Zwickau & 18.6 & Hagen & -2.7 \\
\hline Nürnberg & 37.0 & Leverkusen & 0.0 & Regensburg & 18.5 & Trier & -3.0 \\
\hline Leipzig & 33.2 & Kaiserslautern & 0.0 & Hamburg & 16.7 & Wilhelmshaven & -3.4 \\
\hline Regensburg & 32.2 & Bonn & 0.0 & Fulda & 15.6 & Mönchengladbach & -3.8 \\
\hline Berlin & 31.7 & Paderborn & 0.0 & Lübeck & 14.8 & Oberhausen & -6.4 \\
\hline Oldenburg & 29.1 & Moers & 0.0 & Nürnberg & 13.9 & Hamm & -6.6 \\
\hline
\end{tabular}


Table 3: Prices of newly built apartments: importance of first principal component for each city and of each city for first principal component

\begin{tabular}{|c|c|c|c|c|c|c|c|}
\hline \multicolumn{4}{|c|}{ Share of variance explained by first principal component } & \multicolumn{4}{|c|}{ Weight of each city in first principal component } \\
\hline City & Highest value & City & Lowest value & City & Highest value & City & Lowest value \\
\hline Ulm & 30.1 & Duisburg & 1.1 & Magdeburg & 19.7 & Essen & 3.6 \\
\hline Offenbach (Main) & 24.6 & Bottrop & 0.8 & Dresden & 16.5 & Gelsenkirchen & 3.1 \\
\hline Fulda & 23.3 & Bielefeld & 0.6 & Kassel & 15.7 & Hamm & 3.0 \\
\hline Osnabrück & 23 & Gelsenkirchen & 0.6 & Coburg & 15.6 & Recklinghausen & 2.5 \\
\hline Erlangen & 22.2 & Recklinghausen & 0.5 & Ravensburg & 15.0 & Herne & 1.9 \\
\hline München & 22.1 & Herne & 0.5 & Bamberg & 14.9 & Lüdenscheid & 1.9 \\
\hline Dresden & 22 & Lüdenscheid & 0.4 & Mainz & 14.3 & Bottrop & 1.7 \\
\hline Ravensburg & 21.6 & Oberhausen & 0.3 & Osnabrück & 13.9 & Plauen & 1.3 \\
\hline Friedrichshafen & 21.3 & Remscheid & 0.2 & Fulda & 13.7 & Remscheid & 1.1 \\
\hline Magdeburg & 21.1 & Plauen & 0.2 & Schweinfurt & 13.6 & Oberhausen & 1.1 \\
\hline
\end{tabular}

Table 4: Prices of second-hand apartments: importance of first principal component for each city and of each city for first principal component

\begin{tabular}{|c|c|c|c|c|c|c|c|}
\hline \multicolumn{4}{|c|}{ Share of variance explained by first principal component } & \multicolumn{4}{|c|}{ Weight of each city in first principal component } \\
\hline City & Highest value & City & Lowest value & City & Highest value & City & Lowest value \\
\hline Erlangen & 36.9 & Bergisch Gladbach & 0.5 & Kassel & 23.2 & Salzgitter & 2.6 \\
\hline Ingolstadt & 30.1 & Herne & 0.5 & Landshut & 17.3 & Recklinghausen & 2.1 \\
\hline Kassel & 27.3 & Hagen & 0.5 & Magdeburg & 16.8 & Hagen & 2.1 \\
\hline Friedrichshafen & 26.9 & Bottrop & 0.3 & Regensburg & 16.0 & Herne & 2.1 \\
\hline Wilhelmshaven & 22.1 & Remscheid & 0.2 & Chemnitz & 16.0 & Remscheid & 1.6 \\
\hline Mainz & 21.9 & Mülheim (R.) & 0.1 & Bamberg & 15.3 & Lüdenscheid & 1.4 \\
\hline Freiburg (Br.) & 21.7 & Lüdenscheid & 0.1 & Oldenburg & 15.3 & Bochum & 1.2 \\
\hline Kiel & 20.9 & Bochum & 0.0 & München & 15.0 & Marburg & -0.7 \\
\hline Braunschweig & 20.7 & Plauen & 0.0 & Ingolstadt & 15.0 & Plauen & -1.0 \\
\hline Oldenburg & 18.6 & Marburg & 0.0 & Wilhelmshaven & 14.7 & Mülheim (R.) & -1.2 \\
\hline
\end{tabular}

Table 5: Rents of newly built apartments: importance of first principal component for each city and of each city for first principal component

\begin{tabular}{lc|lc||lc|ll}
\hline \multicolumn{3}{c||}{ Share of variance explained by first principal component } & \multicolumn{4}{c}{ Weight of each city in first principal component } \\
City & Highest value & City & Lowest value & City & Highest value & City & \multicolumn{1}{l}{ Lowest value } \\
\hline Erlangen & 61.9 & Salzgitter & 6.0 & Recklinghausen & 2.1 & Karlsruhe & -12.6 \\
Offenburg & 58.1 & Aschaffenburg & 5.8 & Hagen & 0.7 & Passau & -12.7 \\
Düsseldorf & 56.0 & Oberhausen & 5.2 & Bottrop & -0.8 & Trier & -13.1 \\
Dresden & 54.0 & Remscheid & 4.5 & Wuppertal & -1.8 & Hannover & -13.2 \\
Göttingen & 52.0 & Kaiserslautern & 2.4 & Dessau & -1.9 & Braunschweig & -13.3 \\
Bielefeld & 50.6 & Recklinghausen & 1.7 & Oberhausen & -2.6 & Weimar & -13.8 \\
Ravensburg & 49.7 & Wuppertal & 1.5 & Remscheid & -2.8 & Leipzig & -14.7 \\
Berlin & 49.3 & Dessau & 1.2 & Kaiserslautern & -3.1 & Ravensburg & -15.0 \\
Lübeck & 48.3 & Bottrop & 0.6 & Solingen & -4.0 & Bayreuth & -15.5 \\
Lüneburg & 48.1 & Hagen & 0.5 & Mönchengladbach & -4.1 & Dresden & -18.7 \\
\hline
\end{tabular}


Table 6: Rents of second-hand apartments: importance of first principal component for each city and of each city for first principal component

\begin{tabular}{|c|c|c|c|c|c|c|c|}
\hline \multicolumn{4}{|c|}{ Share of variance explained by first principal component } & \multicolumn{4}{|c|}{ Weight of each city in first principal component } \\
\hline City & Highest value & City & Lowest value & City & Highest value & City & Lowest value \\
\hline Ravensburg & 65.8 & Krefeld & 1.2 & Cottbus & 29.2 & Suhl & -13.6 \\
\hline Lüneburg & 64.5 & Erlangen & 1.0 & Greifswald & 19.2 & Lüneburg & -13.7 \\
\hline Hildesheim & 60.5 & Duisburg & 0.6 & Schwerin & 17.0 & Passau & -13.9 \\
\hline Ratingen & 59.3 & Halle (Saale) & 0.6 & Gera & 15.3 & Hildesheim & -14.0 \\
\hline Suhl & 58.5 & Bielefeld & 0.4 & Chemnitz & 8.2 & Konstanz & -14.6 \\
\hline Gießen & 52.7 & Mönchengladbach & 0.4 & Rostock & 7.3 & Darmstadt & -14.7 \\
\hline Salzgitter & 49.8 & Dessau & 0.3 & Hagen & 5.8 & Oldenburg & -14.9 \\
\hline Lübeck & 49.6 & Recklinghausen & 0.3 & Oberhausen & 3.9 & Ravensburg & -15.1 \\
\hline Schwerin & 48.2 & Gelsenkirchen & 0.2 & Dortmund & 3.7 & Albstadt & -15.9 \\
\hline Darmstadt & 46.4 & Eisenach & 0.1 & Wuppertal & 3.5 & Bamberg & -17.2 \\
\hline
\end{tabular}

Table 7: Price-to-rent ratios of newly built appartments: importance of first principle component for each city and of each city for first principle component

\begin{tabular}{ll|ll||ll|ll}
\hline \multicolumn{3}{l}{ Share of variance explained by first principal component } & \multicolumn{3}{l}{ Weight of each city in first principal component } \\
Highest & Value & Lowest & Value & Highest & Value & Lowest & Value \\
\hline Heidelberg & 47.7 & Berlin & 10.4 & Heidelberg & 20.6 & Salzgitter & -1.5 \\
Mannheim & 47.2 & Kaiserslautern & 8.5 & Coburg & 19.4 & Fürth & -1.6 \\
Erlangen & 39.5 & Plauen & 6.7 & Duisburg & 17.9 & Remscheid & -1.6 \\
Wiesbaden & 39.2 & Lübeck & 2.0 & Jena & 17.4 & Wolfsburg & -1.6 \\
Göttingen & 35.0 & Bottrop & 1.8 & Hanau & 17.2 & Gießen & -1.8 \\
Coburg & 34.1 & Düren & 1.7 & Wiesbaden & 17.1 & Hagen & -1.9 \\
Bonn & 30.4 & Erfurt & 0.8 & Chemnitz & 16.8 & Hildesheim & -2.1 \\
Schwerin & 28.3 & Neuss & 0.3 & Erlangen & 16.5 & Marburg & -4.7 \\
Frankfurt (Main) & 27.5 & Reutlingen & 0.0 & Mannheim & 16.4 & Dessau & -6.6 \\
Jena & 26.1 & Wilhelmshaven & 0.0 & Rostock & 15.5 & Recklinghausen & -16.2 \\
\hline
\end{tabular}

Table 8: Price-to-rent ratios of second-hand appartments: importance of first principle component for each city and of each city for first principle component

\begin{tabular}{ll|ll||ll|ll}
\hline \multicolumn{3}{l}{ Share of variance explained by first principal component } & \multicolumn{4}{l}{ Weight of each city in first principal component } \\
Highest & Value & Lowest & Value & Highest & Value & Lowest & Value \\
\hline Jena & 53.3 & Ratingen & 52.2 & Magdeburg & 23.4 & Flensburg & 0.0 \\
Magdeburg & 50.5 & Düsseldorf & 45.6 & Jena & 19.7 & Bergisch Gladbach & -0.3 \\
Siegen & 47.8 & Neumünster & 44.2 & Brandenburg (Havel) & 17.9 & Düsseldorf & -1.0 \\
Lübeck & 46.6 & Hannover & 31.2 & Herne & 17.0 & Pforzheim & -1.9 \\
Brandenburg (Havel) & 38.2 & Krefeld & 17.9 & Halberstadt & 16.8 & Hagen & -2.6 \\
Neuss & 38.1 & Bayreuth & 16.9 & Landshut & 16.3 & Hanau & -3.3 \\
Hamburg & 36.9 & Erfurt & 14.7 & Suhl & 15.9 & Oberhausen & -4.9 \\
Ingolstadt & 35.5 & Detmold & 13.0 & Ingolstadt & 15.9 & Potsdam & -5.1 \\
Berlin & 35.0 & Bergisch Gladbach & 1.4 & Ulm & 15.4 & Wuppertal & -5.6 \\
München & 29.9 & Flensburg & 0.0 & Regensburg & 15.3 & Recklinghausen & -9.9 \\
\hline
\end{tabular}


Table 9: Panel Chow type test

\begin{tabular}{l|c|ccc}
\hline Variable & Test & \multicolumn{3}{|c}{ Bootstrapped critical values } \\
& statistic & $10 \%$ & $5 \%$ & $1 \%$ \\
\hline Building plots & 0.98 & 1.93 & 1.97 & 2.03 \\
Newly built apartments & 2.64 & 1.92 & 1.95 & 2.02 \\
Second-hand apartments & 1.00 & 1.81 & 1.85 & 1.89 \\
Rents newly built apartments & 1.71 & 1.77 & 1.80 & 1.86 \\
Rents second-hand apartments & 1.82 & 2.12 & 2.17 & 2.26 \\
Price-to-rent ratio newly built apartments & 0.54 & 0.77 & 0.80 & 0.84 \\
Price-to-rent ratio second-hand apartments & 0.43 & 1.07 & 1.11 & 1.17 \\
\hline
\end{tabular}

Table 10: Chow type test for principal components

\begin{tabular}{l|c|ccc}
\hline Variable & Test & \multicolumn{3}{|c}{ Bootstrapped critical values } \\
& statistic & $10 \%$ & $5 \%$ & $1 \%$ \\
\hline Building plots & 1.92 & 1.95 & 2.32 & 3.10 \\
Newly built apartments & 4.87 & 2.52 & 3.03 & 4.19 \\
Second-hand apartments & -0.46 & 2.12 & 2.43 & 3.08 \\
Rents newly built apartments & 3.98 & 2.83 & 3.27 & 4.03 \\
Rents second-hand apartments & 3.47 & 4.10 & 4.60 & 5.46 \\
Price-to-rent ratio newly built apartments & -0.43 & 1.81 & 2.31 & 3.05 \\
Price-to-rent ratio second-hand apartments & 1.16 & 3.55 & 3.99 & 4.96 \\
\hline
\end{tabular}


Figure 1: House prices in Germany, 1970:q1-2013:q4

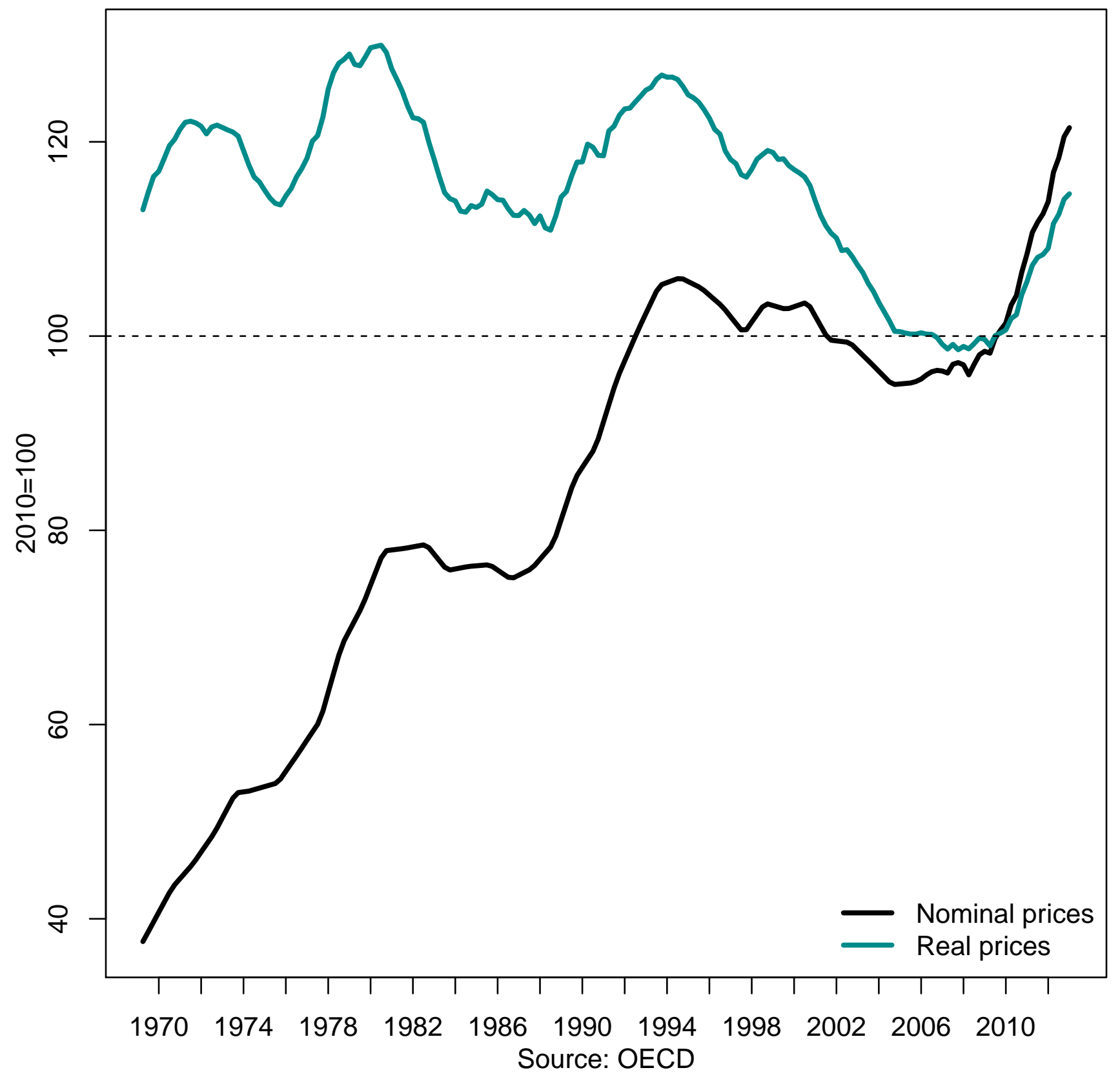


Figure 2: Stylized facts on price development in major economies
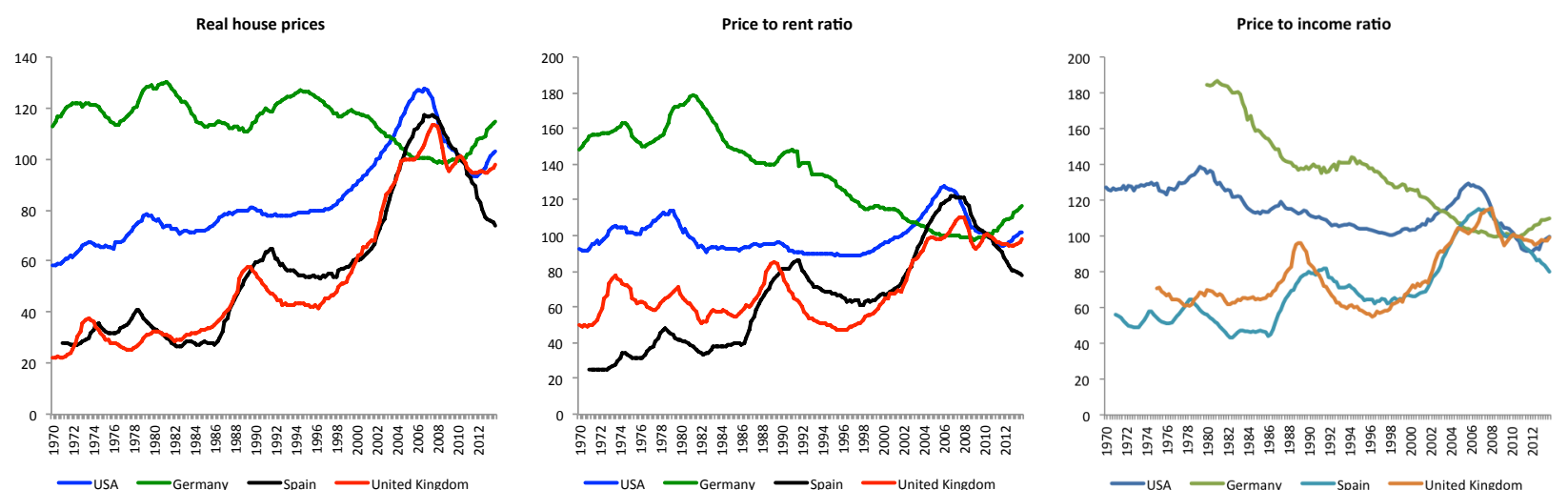

Source: OECD

Figure 3: Stylized facts on housing investment in major economies
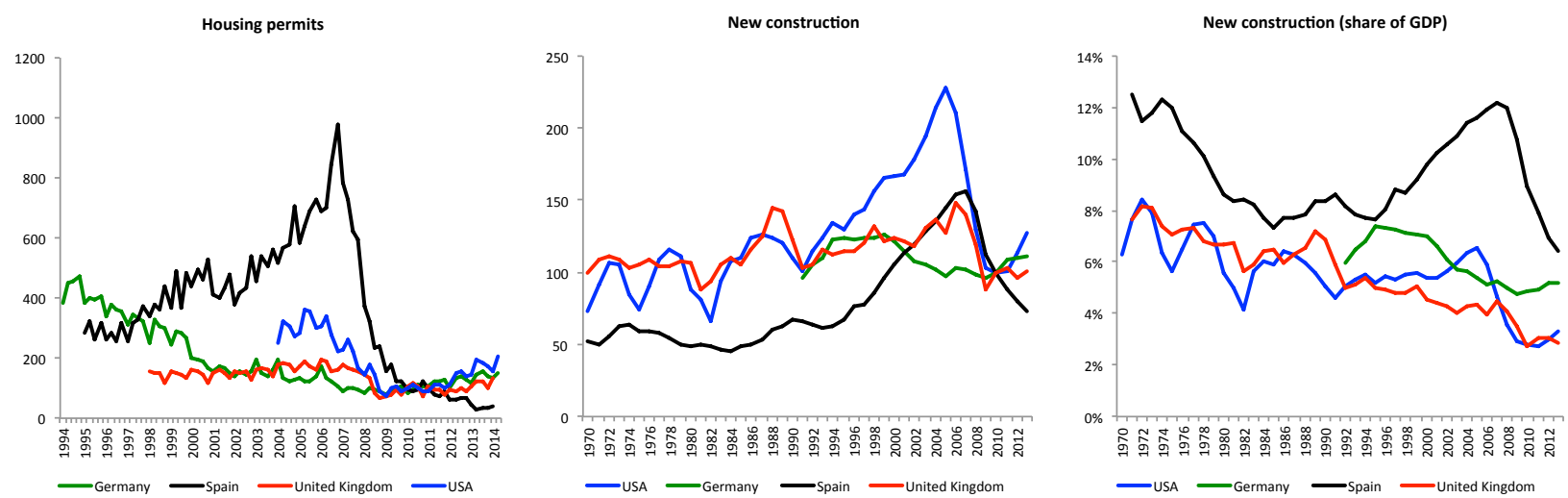

Source: Eurostat

Figure 4: Homeownership rates in major economies (2012/2013)

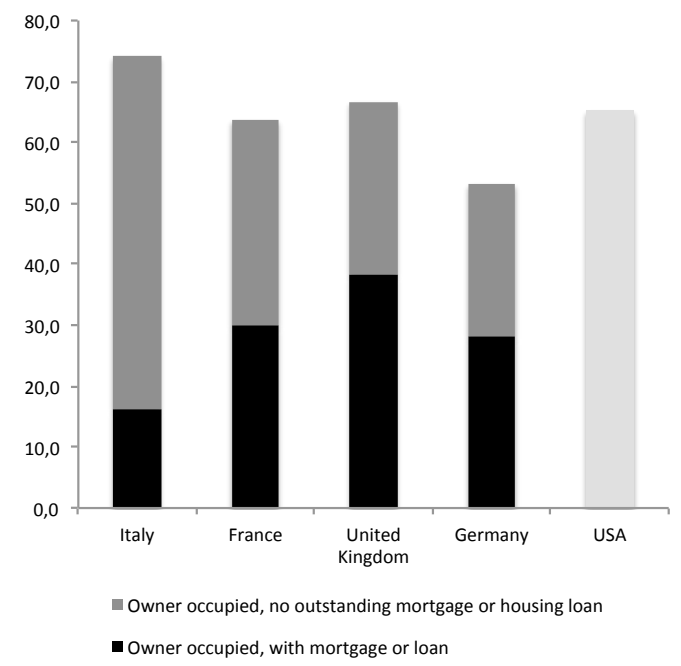

Source: Eurostat and US Census Bureau 
Figure 5: Housing lending in Germany (new loans), 2003:q1-2014:q1 Housing lending

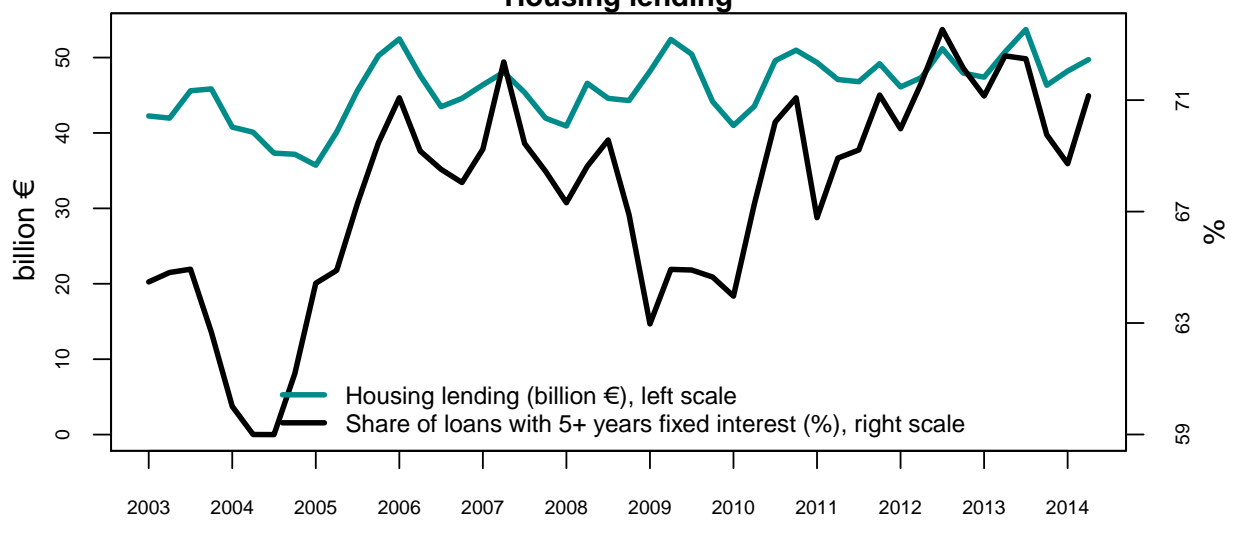

Housing lending to GDP ratio

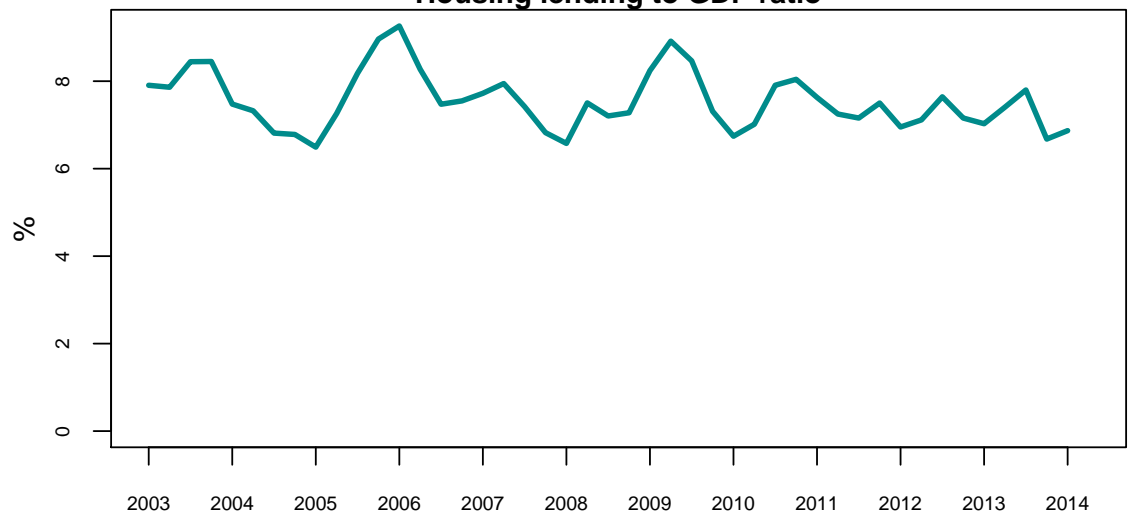

Source: Bundesbank 
Figure 6: House prices in German cities, 1990-2013
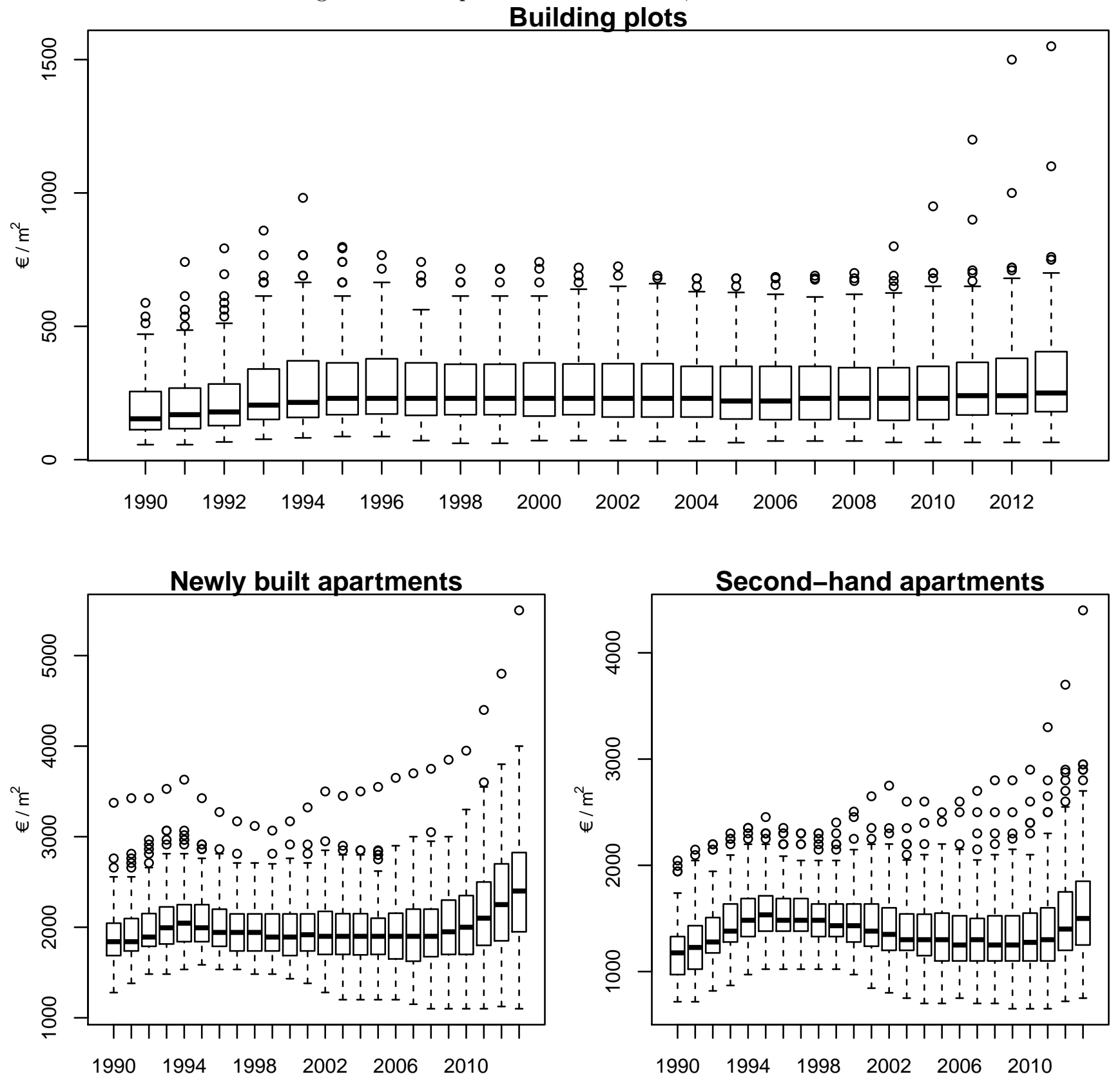
Figure 7: House prices in German cities, 1990-2013
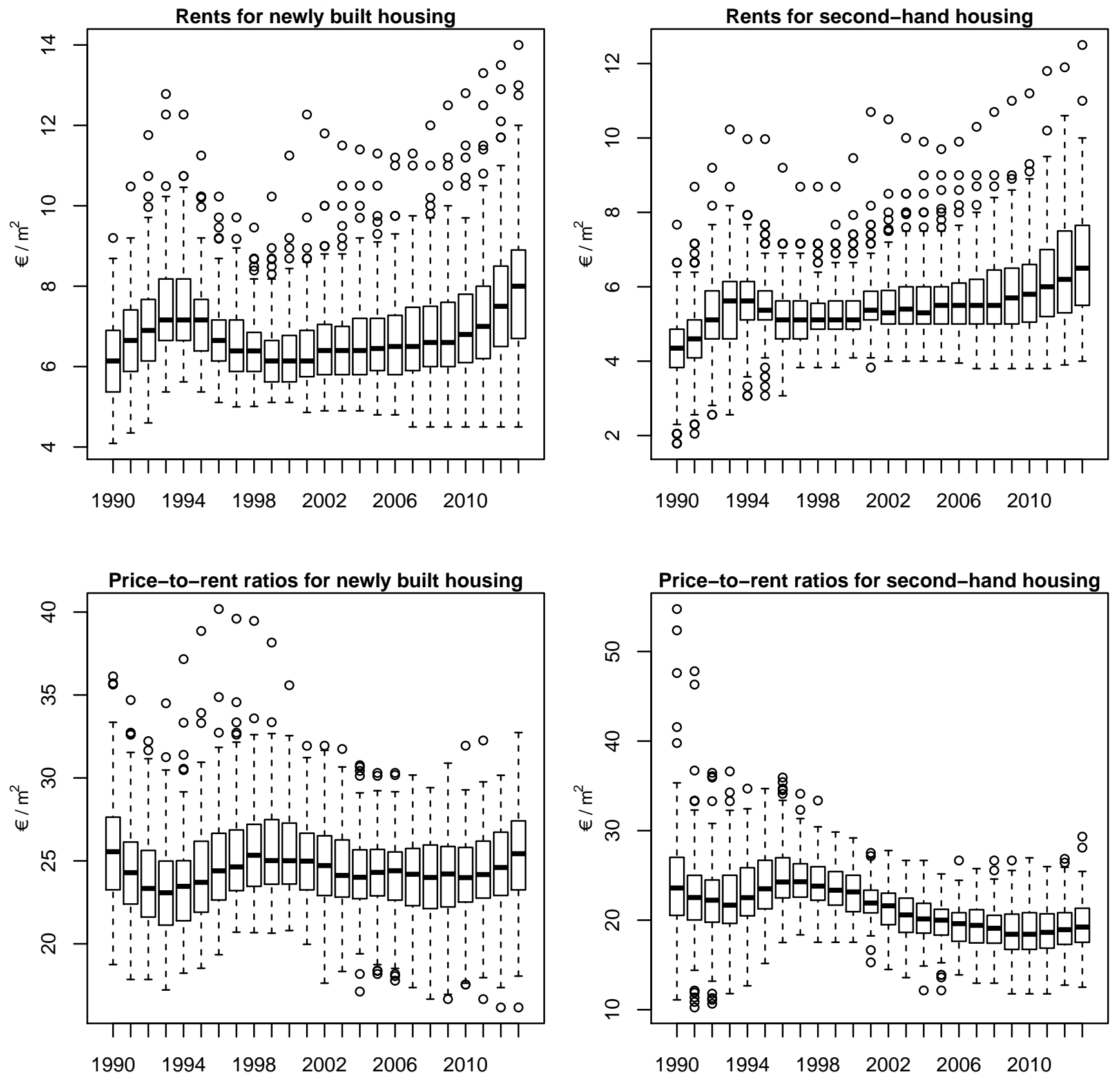
Figure 8: Principal components by share of variance
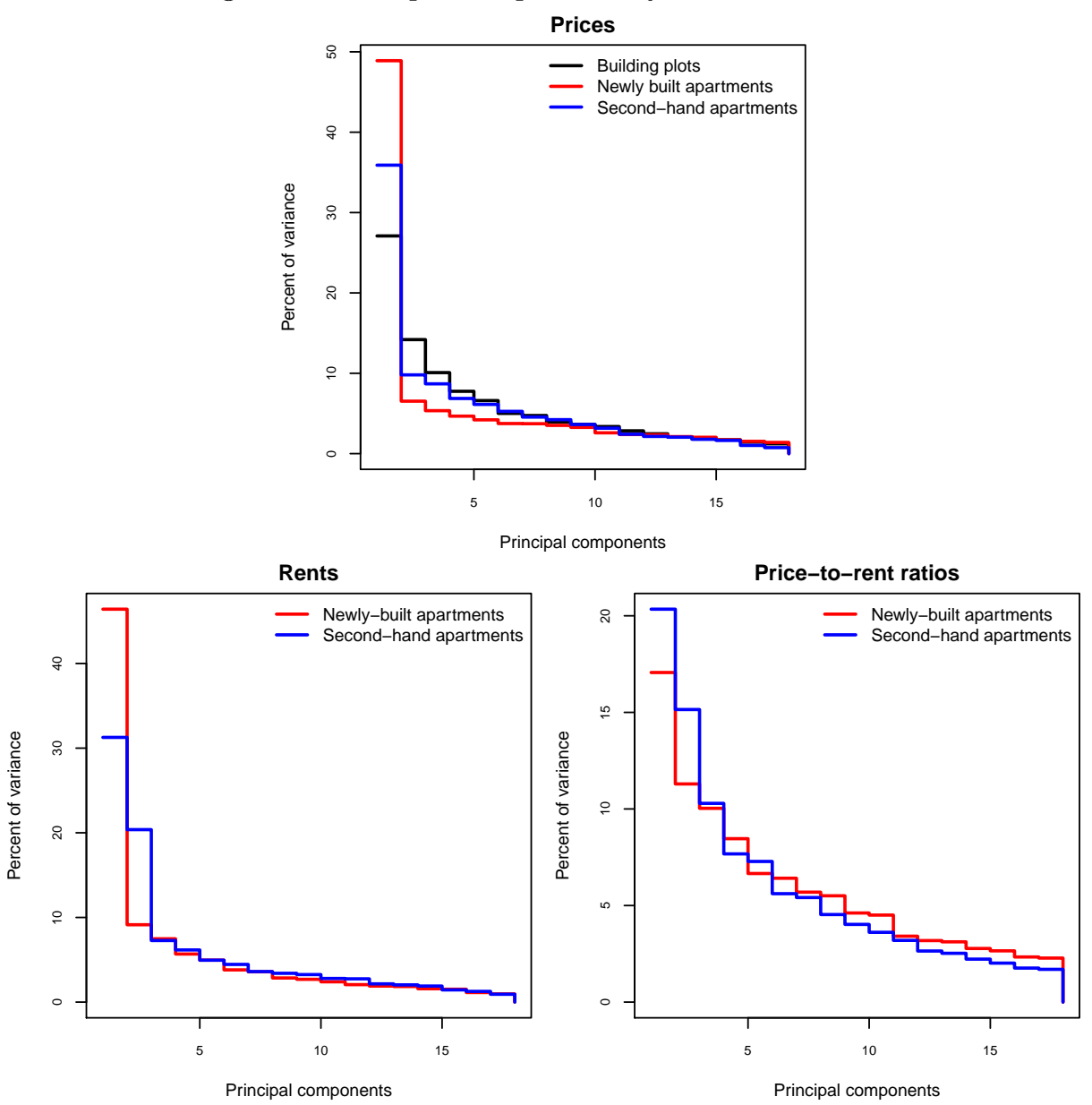
Figure 9: First principal components of housing variables
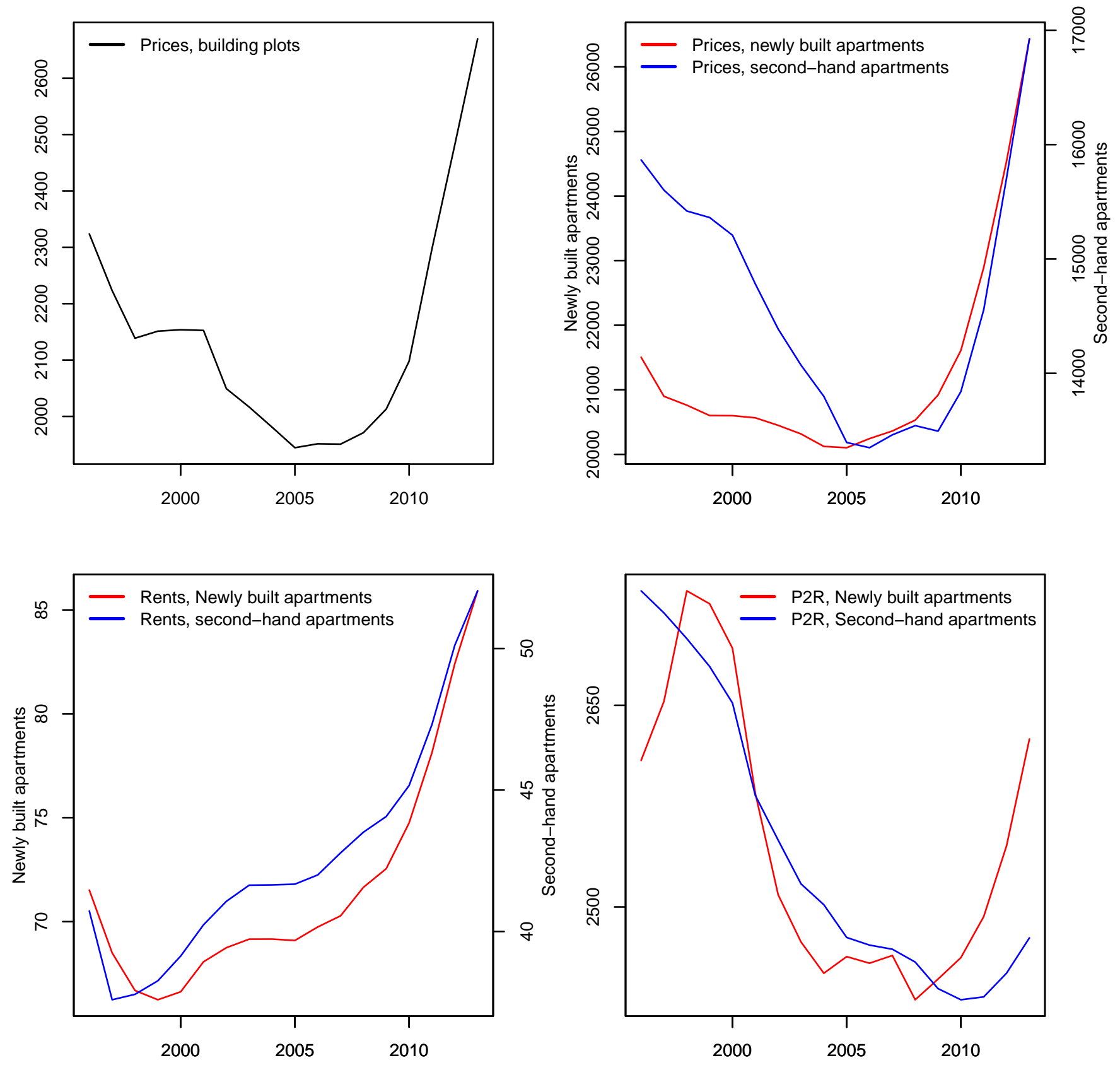
Figure 10: Chow test statistic of principal components of prices
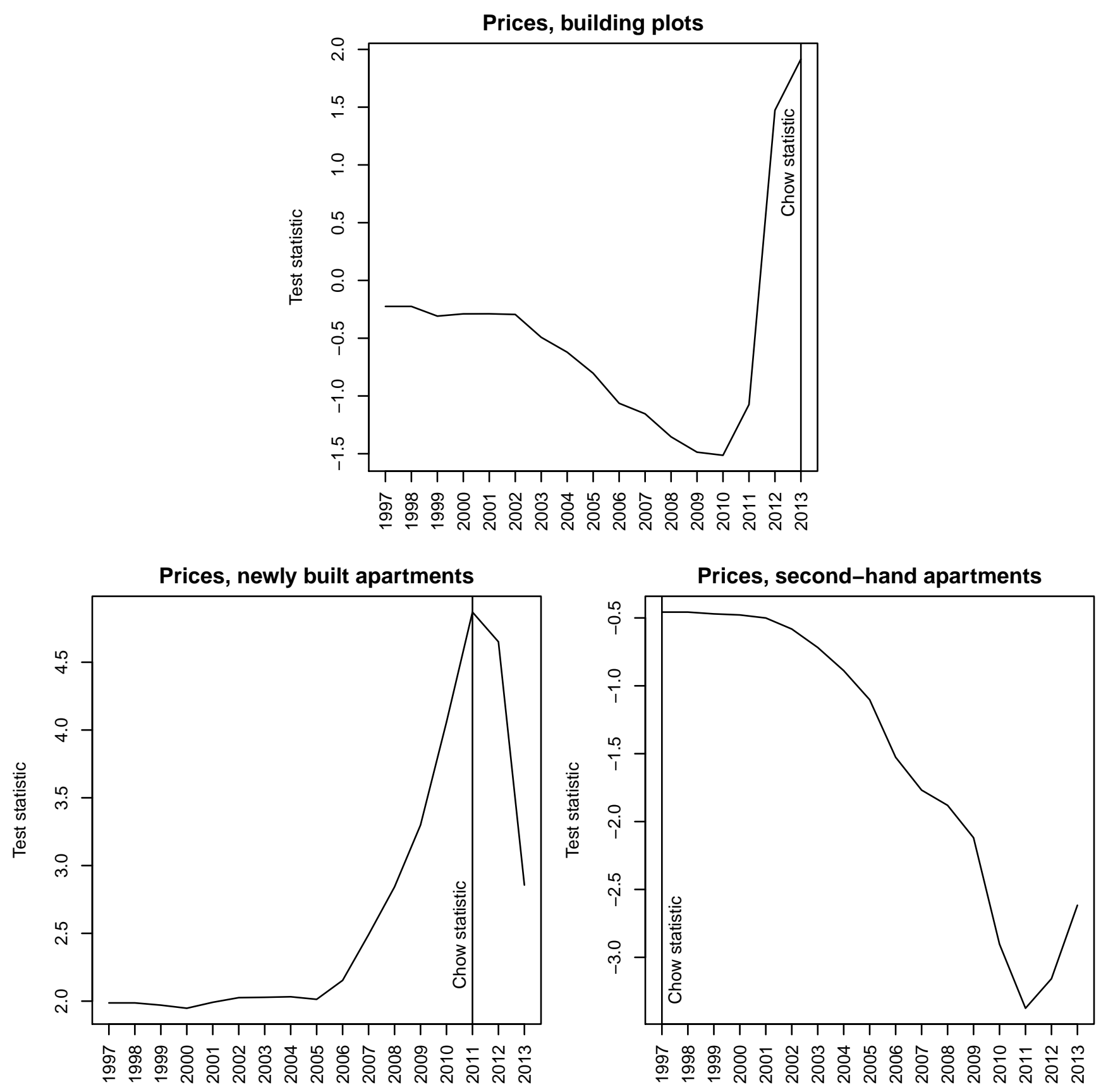
Figure 11: Chow test statistic of principal components of rents, and price-to-rent ratio

Rents, newly built apartments

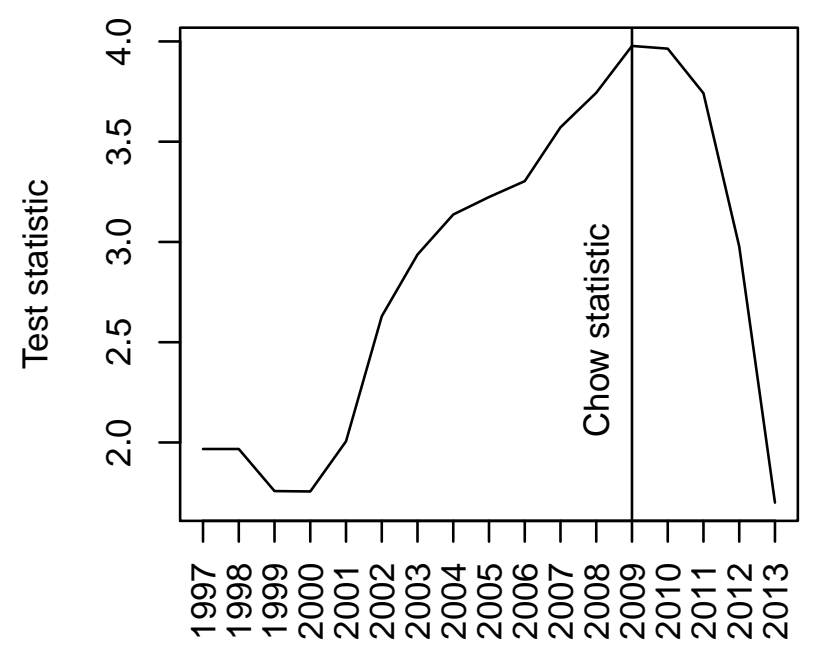

P2R, newly built apartments

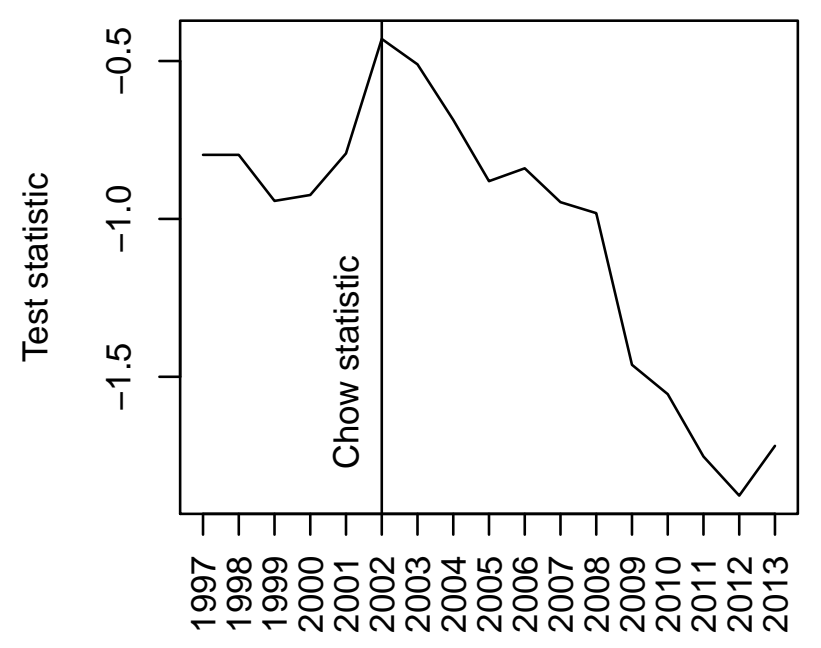

Rents, second-hand apartments

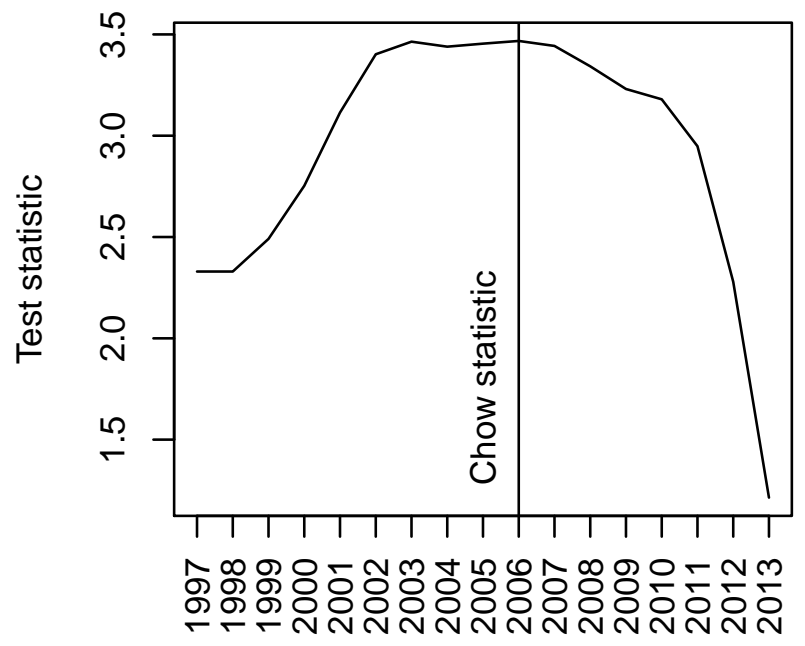

P2R, second-hand apartments

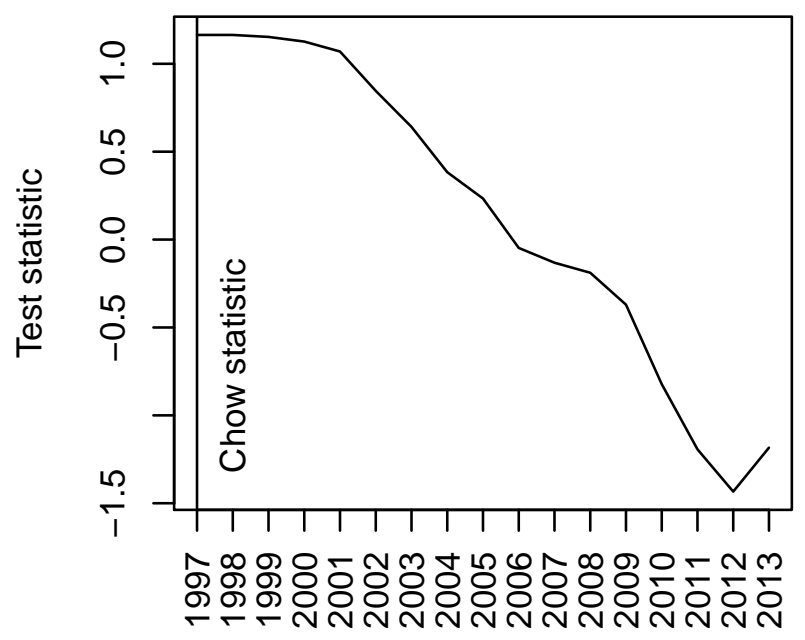


Figure 12: Geographical distribution of explosive roots, prices

- No explosive roots

- Explosive roots 1 market

- Explosive roots in 2 markets

- Explosive roots in 3 markets

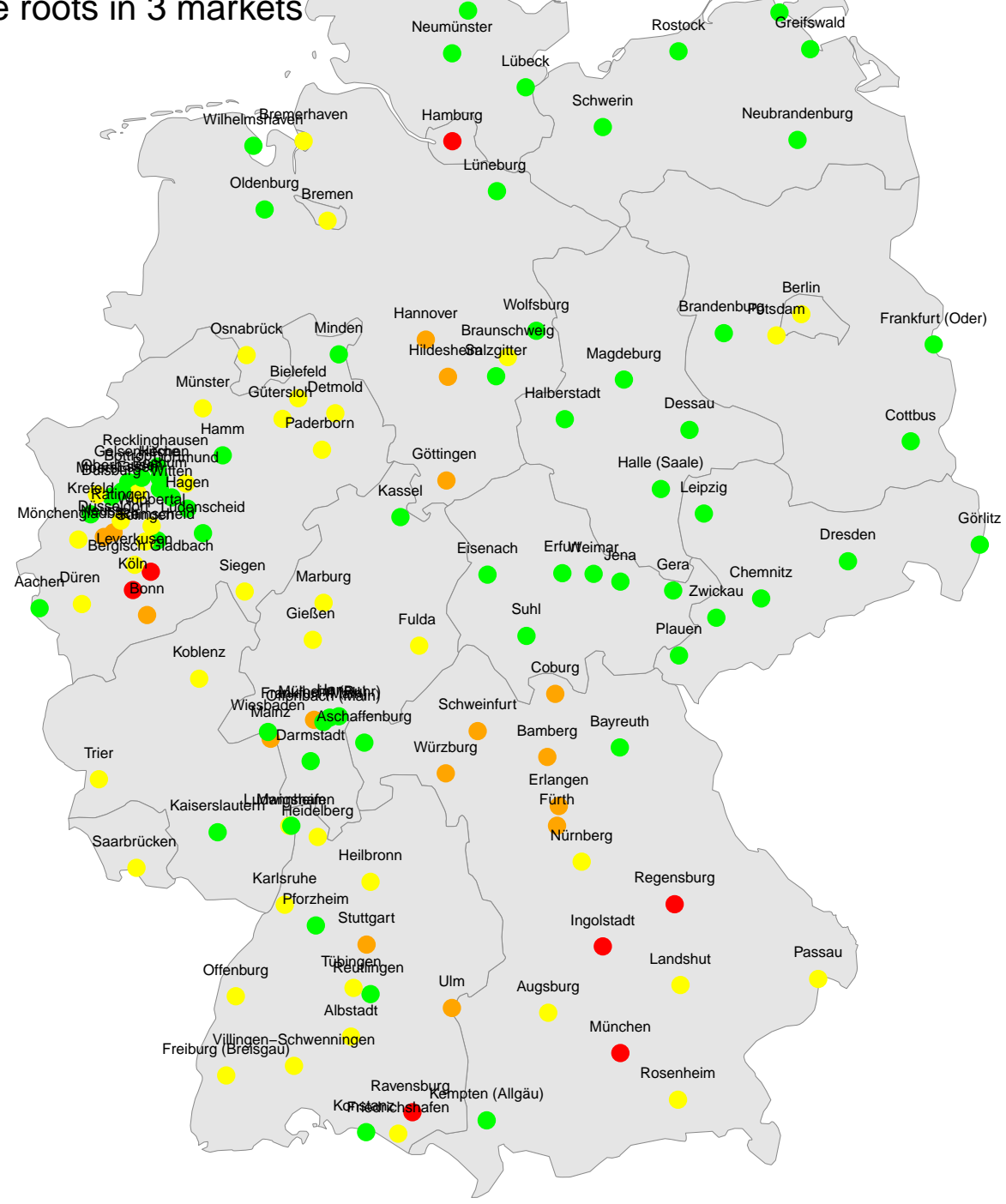


Figure 13: Geographical distribution of explosive roots, rents

- No explosive roots

Explosive roots 1 market Fensourg

- Explosive roots in 2 markets

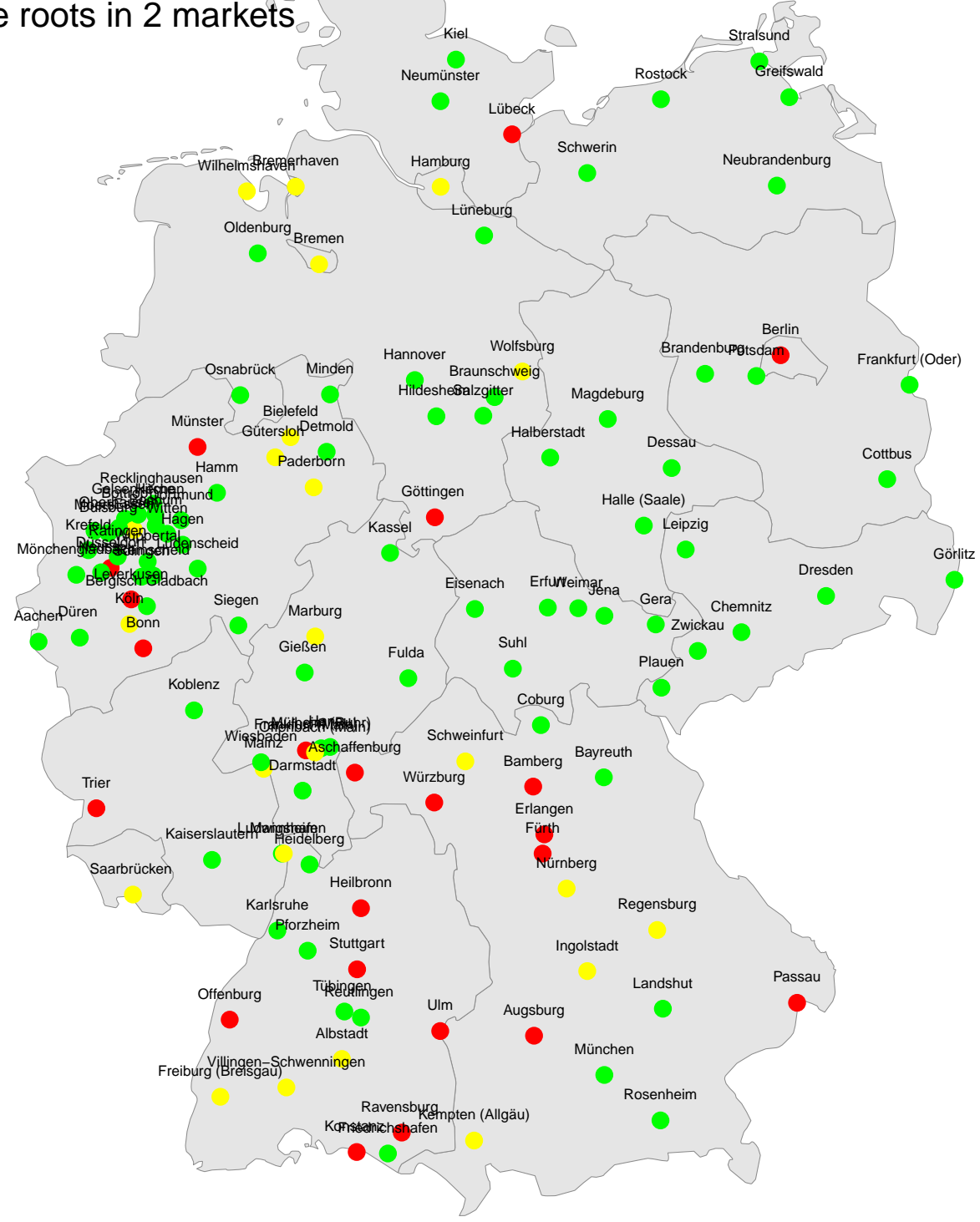


Figure 14: Chow test by city for prices, rents, and price-to-rent ratios

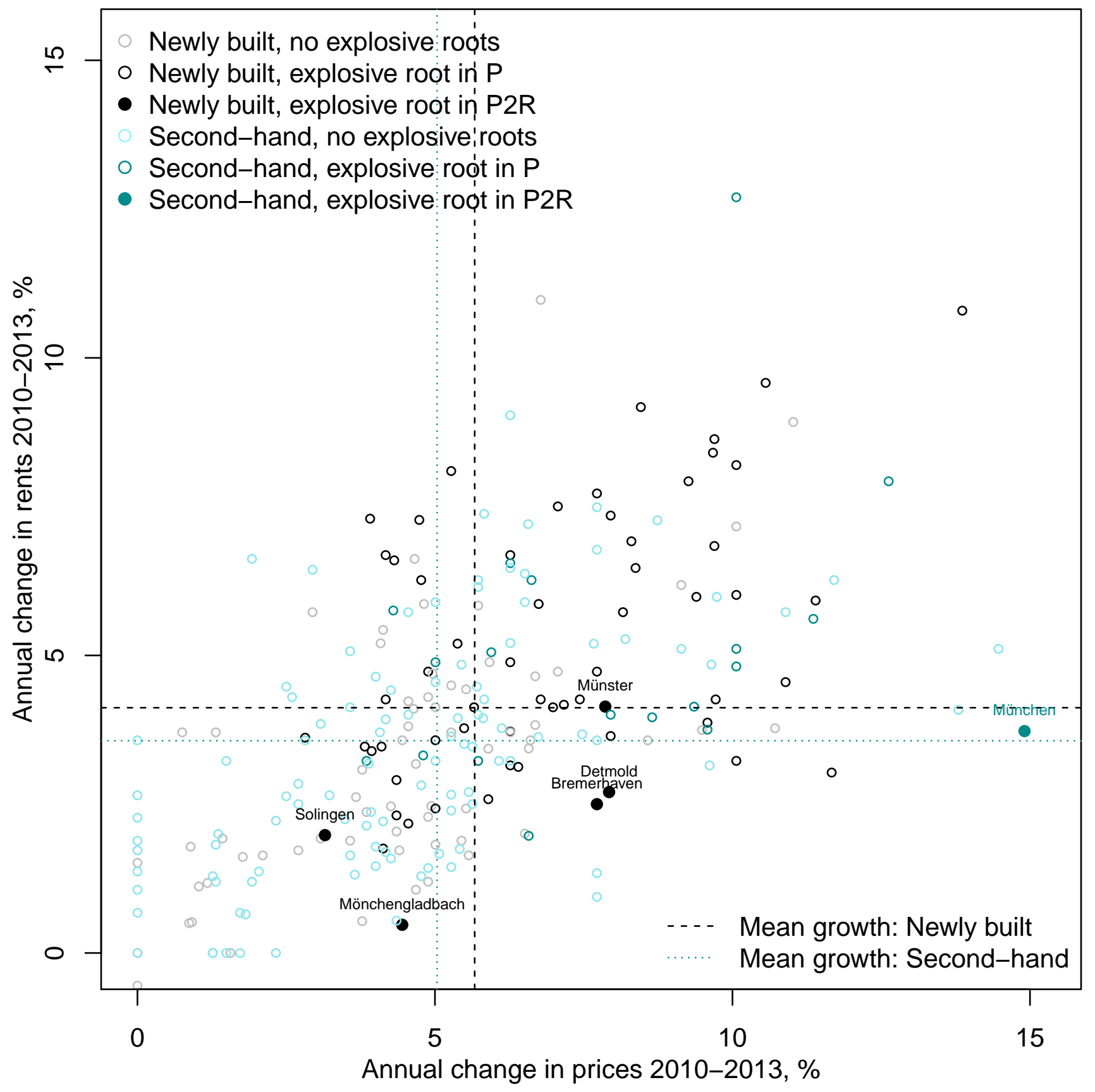

